骨移植に続く歯槽骨変化のマイクロラジオグラフィ, ラベリング法

と血管造影による研究

一一自家腸骨と kiel bone 移植との比較観察 (1) -

寺辺勝之・千葉博茂・園山昇

\title{
Studies on the changes occurring alveolar bone following bone transplantation by means of microradiography, labelling method and angiography
}

\section{Comparative observation with iliac bone and kiel bone transplantation (1) -}

\author{
Katsuyuki Terabe $\cdot$ Hiroshige Chiba - Noboru Sonoyama
}

\begin{abstract}
To study structural changes which occur following bone transplantation along with internal remodelling of a transplanted bone, its surrounding alveolar bone and the jaw bone in the remote area, autogenous iliac bone and kiel bone were transplanted into the left and right lower jaw, respectively, of adult dogs. Time tracing was performed by using three labelling agents (tetracycline, calcein, alizarin complexone) during the experiment (6 to 184 days after bone transplantation). Angiography was also conducted prior to the animals' sacrifice. Microradiograms, labelling findings and angiograms obtained from large ground sections prepared from the lower jaw were compared. The following results were obtained.

In both the left and right transplantation beds, capillary blood vessels newly developed at the transplantation site showed a network-like proliferation and developed in the transplanted bone prior to new bone formation around the transplanted bone. Almost simultaneously with this change, absorption of the existing bone and new bone formation became active in the interior of the alveolar bone around the transplantation bed.

The new bone in the transplantation beds showed compact proliferation 10 days and 30 days after transplantation of the iliac bone and the kiel bone, respectively. The degree of calcification became almost the same as that for the surrounding alveolar bone 60 days and 120 days, respectively, after transplantation.

With the new bone formation in the transplantation bed that received the kiel bone, addition of bone proceeded actively around the bed, in the interior of the alveolar bone on the surface layer of the remote region and in the compact bone facing the mandibular canal in the lower margin (lining phenomenon).

The patterns of new bone formation in the bed that received the iliac bone included a new bone proliferation from the base toward the apex of the transplantation bed in one case, and gradual replacement of the transplanted bone by new bone originating in the surrounding area of the transplanted bone in another case. By contrast, the kiel bone was replaced almost entirely by new bone developing around the transplanted bone. The iliac bone and kiel bone
\end{abstract}

日本菌科大学歯学部口腔外科学教空第 2 講座

(主任：園山 昇教授)

The Nippon Dental University, School of Dentistry at Tokyo, Department of Oral and Maxillofacial Surgery II (Chief: Prof. Noboru Sonoyama) 受付日：昭和63年 5 月 25 日 
were absorbed and had disappeared by about 30 days and 140 days, respectively, after transplantation.

These changes in the kiel bone transplantation group were observed later than those in the iliac bone transplantation group. The process of their appearance was influenced by individual differences, age, transplantation material, etc.

Absorption of new bone in the transplantation bed began about 60 days after transplantation, and it continued even up to 184 days after transplantation. Therefore on the side that received the iliac bone, the site around the apex of the transplantation bed and its vicinity became compact, while the base became porous. On the side that received the kiel bone, bone absorption and addition were repeated, with the result that the base of the transplantation bed was occupied by bone trabeculae which were highly calcified.

Key words: bone transplantation, bone calcification, and angiography

緒

言

\section{実験材料と方法}

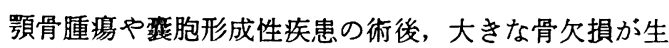
ずることは，口腔外科領域ではまれではない，その際， 即時再建手術に用いる移植材料のらち,なかでも新鮮自 家骨が優れており,これらについては, 1867年, Ollier ${ }^{1)}$ が移植骨に関する実験的研究を報告して以来, 多数の 研究者により骨移植後の治瘾過程, 特に, 移植骨の運命 などについて検討が加えられ，臨床的だけでなく実験的 にもあきらかにされてきた。しかし，採取できる骨の長 さと, 厚みには限りがあり, 移植骨採取に際して生体に 対する侵襲を考えあわせると，できればすぐれた代 用骨の開発が望まれていた． Maatzと Bawermeister $(1964)^{2)}$ らは, 過酸化水素水 $\left(\mathrm{H}_{2} \mathrm{O}_{2}\right)$ で処理した kiel bone graft による異種骨移植法を発表したが, 長期にわ たる詳細な 臨床報告や，基礎的立場からの情報は数少 ない. 結局, kiel bone が自家腸骨に代わり得る移植材 料かどらかは，まだあきらかでないといえる。そこで今 回わたくしたちは, 移植後の kiel bone と自家腸骨の 運命を比較観察する目的から, 成犬の下顥骨欠損部の一 方には kiel bone を，他方には自家腸骨を移植し，ま ず移植骨と周囲歯槽骨内部に起こると思われる,さむざ まな改造性変化を石灰化進行像の立場から，長期にわた って経日的に観察した。このため，実験期間中，種々の 硬組織ラベリング剂投与による時刻描記を行い，下買犬 迷から第 1 大臼歯にわたる大研磨片を作成し，これより 得られたマイクロラジオグラムとラペリング像より所見 の解析を進めたが，さらに，骨の变化に先行すると予想 される血管の走行変化もあわせて観察する目的で屠殺時 に血管造影を行い，同一研磨片から得られたアンギオク ラムも比較観察した。

\section{1. 実験材料}

実験動物は, 雌雄の別なく体重 7 12 kg の健康な㱷 種成犬 9 頭で，固体の年龄はあきらかではないが，歯牙 の萌出状態や咬耗等より生後 $1 \sim 2$ 年前後と推定され た.

これらは日本ペットフード社製固形飼料ビタワンによ って飼育された。

\section{2. 実験方法}

1) 移植部位およびその方法

まず，動物にペントバルビタールナトリウム注射液 （ソムノペンチル，ピットマン・ムーア社）による腹腔 麻醉を行い, 両側の下䫑第 4 小曰歯を抜去し, この部の 歯槽骨に箱型の骨欠損を形成したのち，一方の骨欠損部 には kiel boneを,もら一方には片側の腸骨を採取し 移植した。この部位を選択する理由として千葉 $\left(1976^{3}\right)$, 19794)）の報告を参考にした，すなわち，1）この部の 歯槽骨に箱型の骨欠損を形成する際，それに先立つ抜歯 操作が容易なこと，2）歯列のほぼ中央に位置し，骨移 植に続くさまざまな骨の改造性変化を，移植骨部だけで なく周囲歯槽骨にわたるかなり広い範囲で観察できるか らである。

骨移植を行らにあたって，まず左右両側の第 1 小曰歯 から第 1 大田歯遠心にわたる煩側, および舌側の歯頸部 を切開し，その部より䫅舌側ともに歯肉骨膜を剝離して 歯槽骨を露出, マイクロモーター用ダイヤモンドディス クにより第 1 小田歯の歯冠, 歯根を分割し, 挺子拉よび 下額残根鈷子を用い拔歯した。次に，ストライカーソー を用い注水下に下歯槽管上縁に及ぶ箱型の骨欠損を形成 した.この際, 両隣在歯の㐘根, ならびに下歯槽動静脈, 同神経を損照しないよら注意した。骨移植は左側下影骨 
欠損部には kiel bone, 右側には自家腸骨を採取し, 移 植した. 特に, 移植に用いた kiel bone は皮質骨質を全 く含まないタイプで，海綿骨質のみからなる Spongiosapackung 910420 (Brown 商会) で, この kiel bone を 注水下に, マイクロモーター用骨バーにて骨欠損部の形 状にトリミンクし，移植した，一方，自家腸骨片は動物 の左側腸骨より採取し, kiel bone と同様にトリミング し, 移植した。なお, 左側の腸骨を利用した理由は, そ の湾曲の方向が右側下罘骨に適合がしやすいためであ る. 移植骨は両側とも骨縫合などの固定は行わず, ナィ ロン系で粘膜骨膜弁を縫合し手術を終了した.

2) 䖝光物質による硬組織のラベリングの方法

移植前の歯槽骨内で進行している生理的な新生骨形成 と, 移植後に開始される骨の改造性変化を知るために, 次に述べる 3 種のラベリング剤をいろいろな期間と間隔 で皮下注射した。

(1) テトラサイクリン (Tetracycline)

筇注用の結晶塩酸テトラサイクリン (Achromycin, Lederle, 武田薬品工業）を用い, 動物の体重 $1 \mathrm{~kg}$ 当り $20 \mathrm{mg}$ の割合で, 注射用蒸留水を用いて $2 \%$ 濃度の溶液 を作製した。

（2）カルセイン (Calcein, 和光純薬工業)

動物の体重 $1 \mathrm{~kg}$ 当り $8 \mathrm{mg}$ の割合で, $2 \%$ 溶液を 作製した. 溶解の方法は, 狩山 $(1969)^{5)}$ の報告に従い, $0.05 \mathrm{~N}$ の $\mathrm{KOH}$ 水溶液 $(\mathrm{pH}=12)$ にカルセインの粉 末を溶かし，それをさらに注射用蒸留水にて 2 倍希釈し た.

（3）アリザリンコンプレクソン (Alizarin Complexone)

金属指示薬，ドータイト ALC（和光純薬工業）を用 い, 動物の体重 $1 \mathrm{~kg}$ 当り $35 \mathrm{mg}$ の割合で, 注射用蒸 留水 $10 \mathrm{~m} l$ に溶解した.

注射の方法は, 螢光物質がでさるだ長く体内にとど まっているように皮下注射とした。また，ラベリング斉 の投与方法は，実験期間の短かいもの（移植後 6 日間か 562日間) では移植前に形成された新生骨の運命を知る ため，術前よりラベリングを行い，その投与間隔は毎 4 日であった，一方, 実験期間の長いもの（移植後 121 日 間から184 日間) では術前のラベリングは行わす， 2 種 類または 3 種類のラベリング剤を組み合わせ, 毎 7 日に 注射を行った。

動物は最後の注射の 2 日後に屠殺したがその直前に, ソムノペンチル腹腔内麻酔下に, 総頸動脈より血管造影 を行った.

このように投与された 3 種類のラベリング斉は, 䖝光 顕钽鏡下で, テトラサイクリンは黄金色, カルセインは 緑色, アリザリンコンプレクンンは赤色の䖝光を示すの である.

3）血管造影の方法
ソムノペンチルの腹腔内麻酔下に, 両側の総頸動脈に 順行性にカテーテルを挿入し, Harvard Apparatus 社 製灌流ポンプ (Variable speed peristaltic pump) を用 い注入压 $120 \mathrm{mmHg}$ で， $37^{\circ} \mathrm{C}$ に加温された $10 \%$ へパ リン添加生理食塩水で両側の総頸静脈の切断端より駆血 洗浄したのち，drawing ink (ハャシ社)を注入，血管 造影を行った。

\section{4) 試料の作製方法}

屠殺後，ただちに周囲の軟組織を除去した後下罘骨を 第 2 大田歯の遠心で離断し，10\%中性ホルマリンで固定 後, それぞれ腸骨移植側, kiel bone 移植側の下㴿骨全 体の軟X線写真を撮影した。続いて下䫍犬雬近心部より 第 1 大臼遴遠心部にわたる緃断研磨片を作成するため余 剩の部分をマイクロモーター用ダイヤモンドディスクで 切離した。 通法に従い, 增強アルコール系列で脱水後, styrene monomer で透徹, polyester resin に浸漬, 包 埋，重合，硬化させた。それを砥石により研磨し，約 $700 \mathrm{~m} \mu$ の厚さでアンギオグラムを撮影し，さらに研磨 を進め, 約 $70 \mathrm{~m} \mu$ の研磨片とし、、イクロラジオグラ ム, ラベリング像を撮影した。

\section{5) 観察方法}

(1)マイクロラジオグラフィによる石灰化像の観察

マイクロラジオグラムの撮影には, Softex 社製 contact microradiography 装置 (CMS-2 特註型) を用い

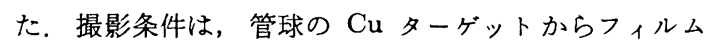
乳剂面までの距離を $20 \mathrm{~cm}$ とし，加速電圧 $20 \mathrm{kV}$ ，管 電流 $10 \mathrm{~mA}$, 照射時間 3 分〜 3 分 30 秒とし，研磨片は Eastman Kodak 社の spectroscopic plate 649-0 の乳剂 面に密着させて撮影した．現像は Kodak 社処方の現像 液 D-158 で, $20^{\circ} \mathrm{C}$ で 5 分間現像後, 停止, 定着, 水 洗, 乾燥し, その後この plateの乳剤面に, カナダバル サムを滴下し，カバーグラスで被った。

次に, このよらにして得られたマイクロラジオグラム を, マクロ写真撮影装置 (Multiphoto, 日本光学株式会 社）を用い白黒フィルムに拡大撮影した。フィルムは Kodak 社の Plus-X を使用した。

\section{(2)螢光顕微鏡によるラベリング像の観察}

研磨片を蒸留水で封入し Leitz 社製螢光顕微鏡 ORTHOPLAN を用い， 3 色のラベリング剂による䖝光像 を観察した。䖝光顕微鏡写真撮影に際し光源側フィルタ 一の 1 次側には UV, BG 3, Blau BG 12, 2 次側には, UV, VGI, Blau BG 12 を, 励起フィルターには, K 515 を使用した。フィルムは, Kodak 社, Ektachrome 100 (ASA 100) を用いた。

次に以上の方法で得られたスライドよりダイレクトプ リントされた写真を貼り合わせて, 試料の全体像を構成 した。しかしこのプリント上ではラベルされた真の石灰 化進行部だけを正確に把握することは困難（血管内の血 球，組織の龟裂部などでは，䖝光を発することが多い） 
なためカラープリント上にポリェステルフィルムをお き，その上にテトラサイクリンラベリング部は赤色, カ ルセインのその部は緑色, アリザリンコンプレクンンは 青色のインクでトレーシングを行った.

(3)血管造影による血管像の観察

研磨片を流動パラフィンで封入し実体顕微鏡（日本光 学社製 SMZ-10, HMF 写真撮影装置) により撮影し た.フィルムは, Kodak 社の plus-X を使用した. 撮 影されたネガフィルムよりプリントされた写真を貼り合 わせて, 研磨片の全体像を構成し, その上にポリエステ ルフィルムを置き黒インクで血管の走行変化をトレース した.

以上, このようにして同一の大研磨片から得られた(1) マイクロラジオグラム像, (2)螢光顕徽鏡写真のトレーシ ング図, (3)血管造影写真のトレーシング図の三者を比較 することにより, 所見の解析をすすめた。

\section{観 察 結 果}

所見の記載に入る前に, 下顎骨の基本的構造, 石灰化 像，血管像について述べてみたい。

1）骨組織の基本的構造

骨組織は外側の緻密な皮質骨部と，それにかこまれる 多数の小骨梁からなる海綿骨部とから成り立っている。 また歯槽骨は歯牙との関係から，固有歯槽骨と支持骨と に区別される，固有歯槽骨は米根膜に接し，雬槽の内壁 を形成している薄い骨質であり，支持骨は歯肉に面する 骨板と，その両者の間を満たす海綿骨よりなっている. すなわち，緻密骨は支持骨のうち齿肉に面する部や下顎 骨外側に，海綿骨は固有歯槽骨と歯肉に面する緻密骨と の間を占めていることになる。

2) マイクロラジオグラム上で見られる骨組織の基本 的石灭化像

マイクロラジオグラムの観察によって，骨の新旧を， そのX線吸収度のちがいで知ることができる。

骨の石灰化は，基質形成後しばらくしてから始まり， 数日以内に 最終石灰化度の $70 \%$ にまで急速に進行する が，その後はきわめてゆっくりと上昇し，最終石灭化度 に達するまでには，数か月を要するといわれている。

3）犬の下顎骨の基本的血管像

移植後の血管像の変化を述べる前に，健康な下䫇骨の 血管像について述べておく.

(1)下顎骨の主要血管

下歯槽動脈は下顎孔より下顎骨内に入り，前下方に向 い各歯根の直下を前走し, 一部は第 2 小曰歯の近くの後 オトガイ孔に枝を出し, 残りの血管は, その後, やや外 上方に向かい, 第 1 小囦宷近くの中オトカイ孔,さらに犬 迷近くの前オトガイ孔に出る。その間，それぞれの槽間 中隔および根管中隔に太い枝を樹枝状に分枝している.
また各根尖孔へ直接下歯槽動脈より小血管が侵入してい る.

(2)緻密骨内の血管

血管は主として近遠心的に走行し，粗な血管網を形成 している，骨膜および骨髄内血管との連絡もわずかであ るが，一部では静脈が他に比較して著しく太い洞様毛細 血管を形成している.

(3)骨髄腔や海綿骨内の血管

下歯槽動脈より樹枝状に分枝した血管は，さらに細か く枝分れしてきわめて密な血管網を形成している，この $2 つ の$ 領域での血管の走行は類似しているが，海綿骨内 の分布密度は骨髄腔内に比較して粗のようである.

マイクロラジオグラフィ, ラベリング法, とアンギオ グラフィによる観察所見

\section{移植後 6 日目例 (図 1)}

マイクロラジオグラム上では, 移植された腸骨や kiel bone の骨梁はよく保たれ，その骨梁の配列やX線吸収 度には特別な変化は認められない.いずれの側にも，移 植骨や移植床の底部や側壁，その周囲の歯槽骨の骨梁間 にはまだ新生骨を思わせる骨質の形成は認められない.

ラベリング像によると移植骨のらち，腸骨の骨梁表面 は全体的に, 均一に, 移植前28日間，4 日間隔で注射さ れたカルセインによってラベルされている，そのラペリ ングの密度は移植床に隣接する歯牙を囲む歯槽骨のそれ よりもわずかに高い. 移植された腸骨や kiel bone の 骨梁間には，まだテトラサイクリンでラペルされた新生 骨の形成はみられない。ただし，kiel bone 周囲，特に 底部の歯槽骨のラベリングの密度は移植腸骨周囲のそれ よりも高く，カルセインでラベルされた骨梁表面の各所 にテトラサイクリンによるラペリング部が認められる. さらに各歯根周囲のラベリング像を観察すると, 腸骨, kiel bone 移植側とも，第 1 小曰歯から第 1 大曰歯に及 ぶ歯槽骨の歯根膜に面する骨質にはテトラサイクリンや カルセインによる幅広いラベリングが見られない.すな わち，実験期間中，雪牙の移動はいずれの歯牙にも起こ っていなかったと想像される。ただ，第 1 大曰歯の各 歯根の近心側雪根膜に面する歯槽骨表面にはテトラサイ クリンによるラベリング部が多く散在している。 それに 比べて遠心側霜根膜面ではそのよらな変化は少ない.

アンギオグラム上では, 移植腸骨周囲の歯槽骨のう ち, 近心側壁や底部を棈成している一部の歯槽骨内部 に，細い網目状の血管の新生が開始される。しかし，そ の分布密度は低い. kiel bone 移植側では血管新生を思 わせる変化はまだみられない。その他，それより遠隔部 の函槽骨内部の血管の走行には大きな変化は見られな い.

\section{移植後10日目例 (図 2)}

マイクロラジオグラム上では，いずれの侧とも移植床 に面する荬槽骨内部には，既存の骨梁表面に砂粒状の新 

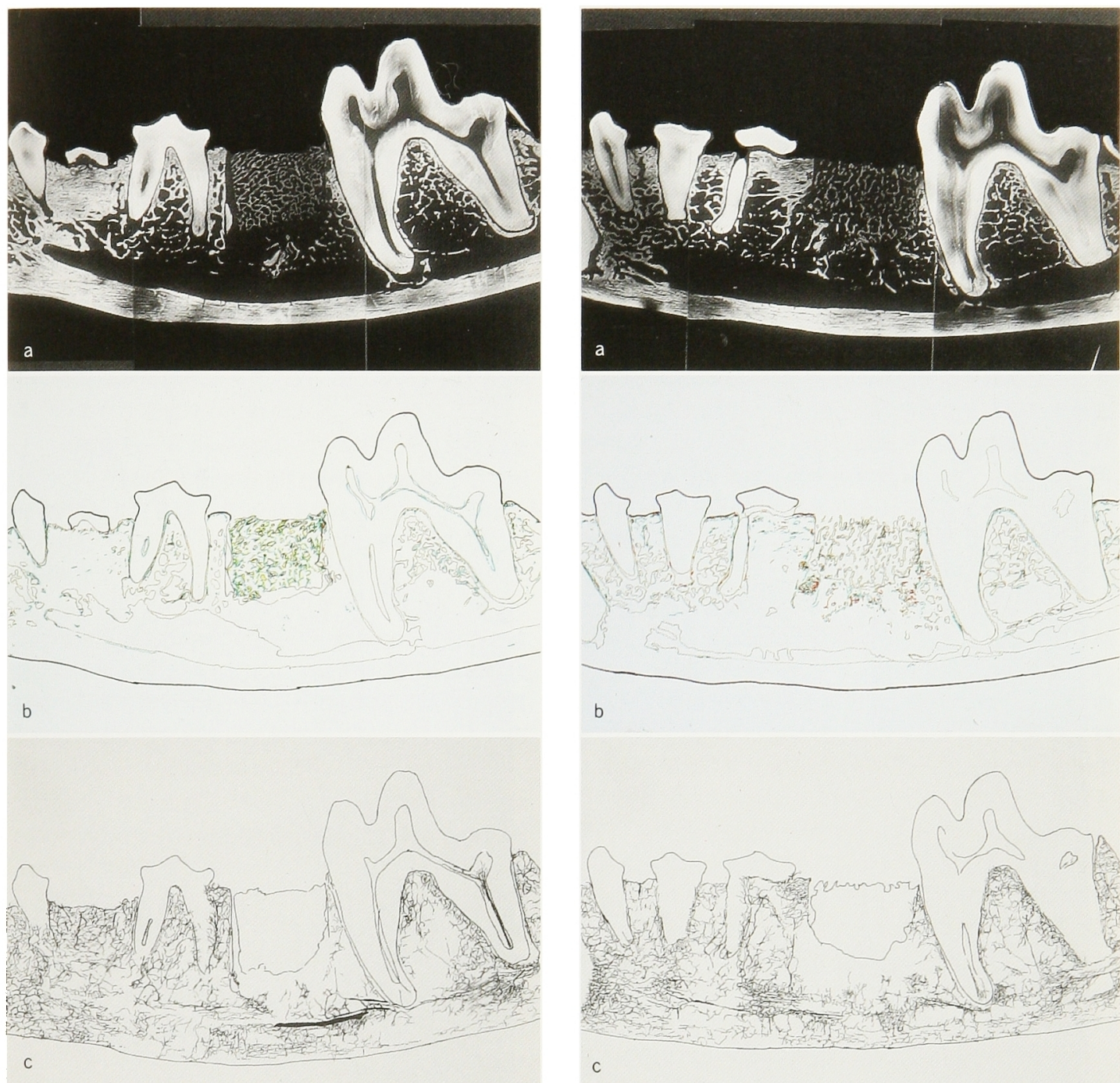

腸骨移植側
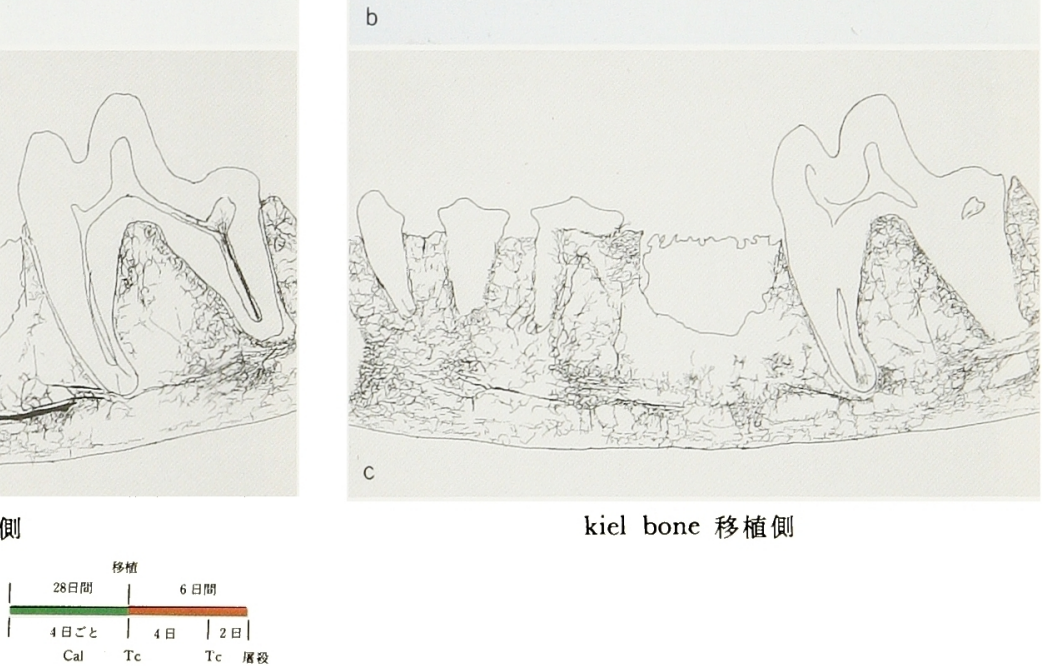

kiel bone 移植側

图 1 移植後 6 日目例

$$
\begin{aligned}
& \mathrm{a} \text { マイクロラシオタラム } \\
& \mathrm{b} \text { ラベリング像(トレーシング园) } \\
& \mathrm{c} \text { 血管造影像（トレーシング図） }
\end{aligned}
$$

生骨の幅広い添加が認められる。その変化は移植床の底 部から下䫇管に面する歯槽骨内部と, 遠心側壁と第 1 大 臼歯の間を占める広い範囲の骨梁の表面にみられ，新生 骨は一部移植骨の骨梁間へも進入しているようにもみえ る。それらの部分のX線吸収度は周囲の歯槽骨のそれ
に比較してかなり低い。ただし，腸骨と kiel bone 移 植側とも新生骨梁の分布密度やX線吸収度にはそれほど の違いはない，ただ，ここで注目されるのは，移植され た腸骨の骨梁内部にはすでに活発な吸収機転が開始され ていることである，それは，特に移植骨の底部で著明 

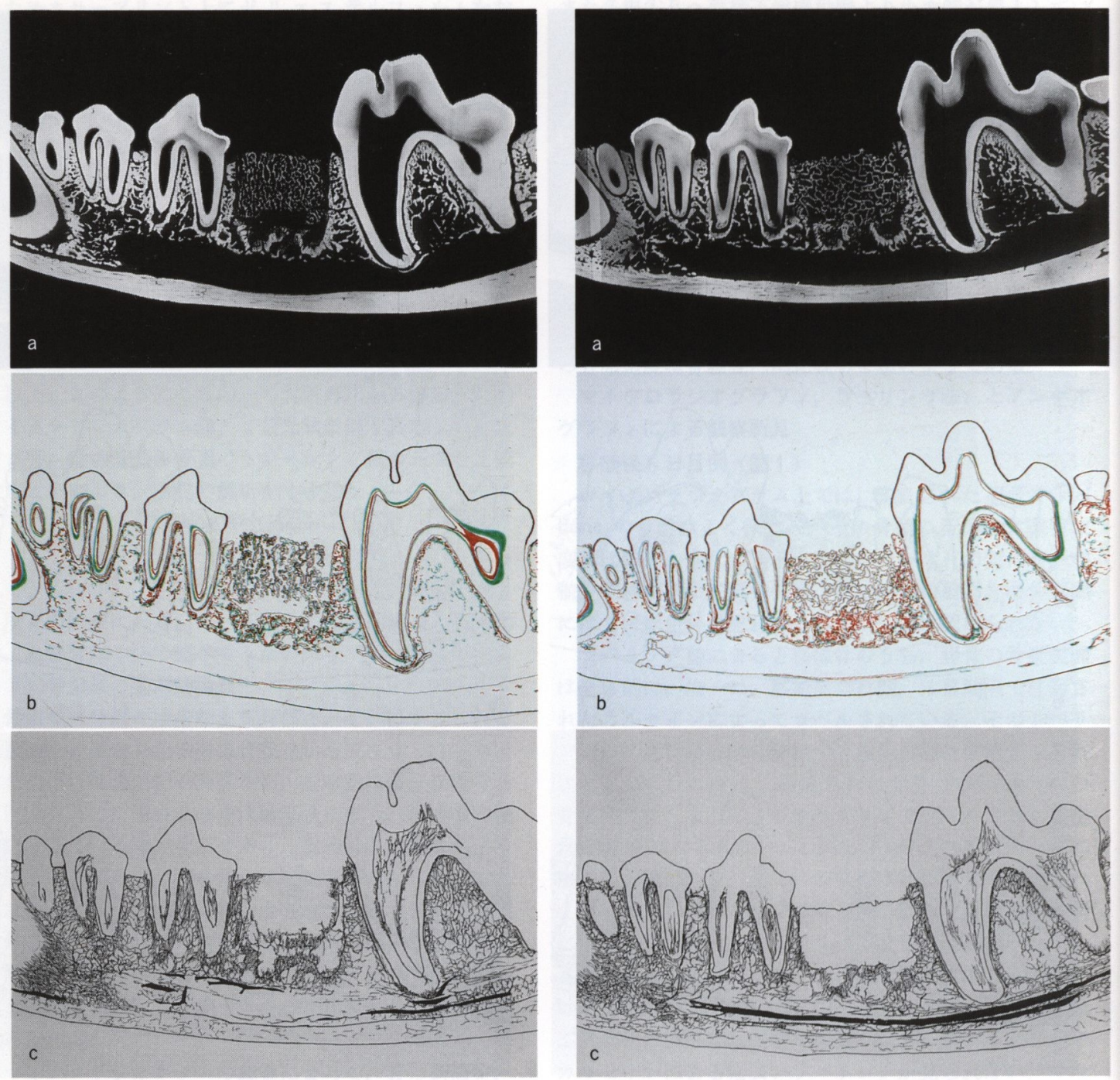

腸骨移植側
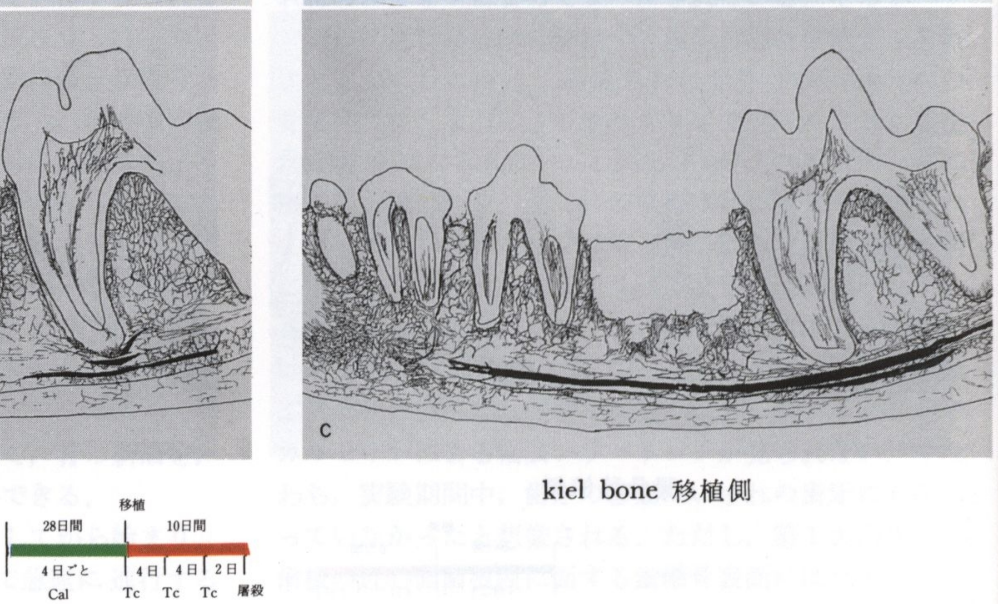

kiel bone 移植側

図 2 移植後 10 日目例

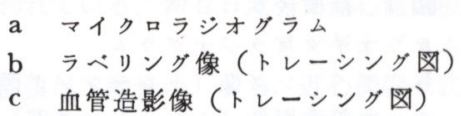

で，遠心側にも及んで扣りその部の腸骨は不規則に陥凹 し，X線透過性のスペースが介在している，ただし， kiel bone の骨梁にはまだ吸収に伴なら変化はみられな い.

ラベリング像で観察すると, 移植された腸骨は移植前
28日間，4 日間隔で注射されたカルセインによってラベ ルされている. 移植腸骨と kiel bone のいずれ側です, その骨梁間の各所, 特に第 3 小目崡と第 1 大田歯に面す る隅角部の移植骨の骨梁間には，移植後から4 日間隔で 注射されたテトラサイクリンによってラペルされた小骨 
梁の散在が認められる．テトラサイクリンのラベリング 部はこのほか, 移植床に面する歯槽骨のらち，低部と遠 心側壁部の骨梁間にきわめて強く観察され，特に底部の 下㴿管上縁に及ぶ骨梁にはカルセインでラベルされた骨 梁表面の各所にテトラサイクリンの幅広い沈着が認めら れる。遠心部側壁では底部に比較して，テトラサイクリ ソによってラベルされた骨質の形成は少ない。ただし， ここで興味深いのは，これとは近の変化が移植腸骨骨梁 の底部や遠心側壁の一部に生じていることである。すな わち，その部のカルセインによるラベリング部は主に吸 収変化によって消失して不規則な外形を有しており，か つての骨梁は軟組織によって占められている, kiel bone ではこのような変化はみられない。

以上の所見とマイクロラジオグラム上の所見を合わせ 考えると，移植床に面する周囲歯槽骨には腸骨や kiel bone 移植後 6 日目頃より 10 日目頃までの間に，新生骨 形成が開始される。それは特に移植床底部で著しく，幅 広い新生骨質の添加がみられ，一部は移植骨の骨梁間に も進入しているようにみえる。一方，移植された腸骨に は吸収機転が活発化する。それは，特に移植床底部と遠 心側壁に面する骨梁間で著しい、腸骨骨梁間には砂粒状 の骨質の形成も進行するが，それにも増して活発な骨質 の吸収のため, 移植腸骨は不規則な外形を呈し，その部 は軟組織によって満たされるようになる。

さらにラベリング像とマイクロラジオグラム像の全体 像を観察すると，第 1 大臼歯の各根の近心側㮀根膜に面 する歯槽骨表面にはテトラサイクリンでラベルされた幅 広い骨の層と，それより内方には移植前28日間，4 日間 隔で注射されたカルセインでラベルされた幅狭い骨の層 が形成されている，しかもテトラサイクリンでラベルさ れた骨の層は周囲歯槽骨より明らかにX線吸収度が低 い.この所見は歯牙が遠心に歯体移動していることを 示している.ところが第 1 小臼雨から第 3 小臼歯にかけ て，これとは全く逆の変化が生じている。すなおち各根 の遠心側歯槽骨表面に幅広いテトラサイクリンの層，そ の内方に幅狭いカルセインのラベリング層が形成されて 扣り，従って雨牙はいずれも近心に歯体移動しているこ とがわかるのである。犬の生理的歯牙移動に関する実 験6) では下顎の第 2 , 第 3 小臼歯を境にして, 前方の歯 牙は近心に，後方の霜牙は遠心に歯体移動するといわれ る.この結果からこのような変化は生理的兩牙移動に伴 ら変化と考えられるが，骨移植によってもその移動の方 向に変化が生じなかったことが想像されるのである。ま たこの時期にはいずれの側でも，移植床の下方の，下買 管に面する下縁部緻密骨の表層にテトラサイクリンによ る幅狭いラベリング層が出現する．以上の変化は骨移植 によってその前後の歯牙の移動の量と方向に何らの変化 が生じなかったのに，それよりも離れた下䝷管下縁の緻 密骨に新生骨が急速に形成されたことを示哱している.
アンギオグラムでは，移植腸骨の周囲から新生した毛 細血管は主に $2 つ$ 部分でその数と分布密度を増してい ることがわかる（11そのひとつは活発な骨吸収が進行し ていると想像される部分に起こる変化で, 移植腸骨の底 部や側壁部の周囲に増生する血管網である。そこでは， 細長い毛細血管が繊毛状に不規則に配列し，移植骨梁内 に進入しているようにみえる。（2)もらひとつは，移植休 の底部や側壁部の周囲で活発に新生骨を形成している部 分にみられる毛細血管の配列である。そこではきわめて 細く，短い毛細血管が多数增殖し，各所で血管網を構成 している.

一方, kiel bone 移植側では移植骨の吸収に伴うよう な毛細血管の増生はみられない、毛細血管は移植床の底 部や側壁部で，細かい網目状構造を形成しており，その 部分では新生骨形成が活発に進行している。その他，第 3 小臼歯や第 1 大臼歯の根間中隔部や，さらに遠隔部の 毛細血管の走行にはいずれの側でも大きな違いはみられ ない.

\section{移植後14日目例（図3）}

移植後10日目例に，すでに移植床底部と側壁部から形 成されつつあった新生骨梁は，移植後14日目にはいずれ の側とも移植床の $1 / 3$ を満たし，急速に増生してその 分布密度も次第に緻密になることがわかる．しかし，14 日目では10日目に比較して骨梁の幅の増加は比較的少な いこれらの新生骨梁のX線吸収度は周册の歯慒骨のそ れよりもかなり低く，全体として均一な石灰化度を示し ている。しかも新生骨梁の幅はまだ既存の歯槽骨のそれ よりかなり細く，分布密度も低い，移植床底部に新生骨 が增生すると，いままで移植床を占めていた移植骨は， 移植後14日目にはますます吸収され，すう粗化が進行し ている，腸骨移植側では吸収は移植床底部と側壁部に沿 らょうに拡大し，同時に腸骨骨梁内部でも進行するた め, 移植骨はわずかに移植床内に残存するだけとなり, 新生骨との間にはX線透過性の幅広いスペースが介在し ている。一方, kiel bone 移植側では, 吸収は主に側壁 部より進行するため, 移植床底部にはまた kiel bone が 大部分残存しているが，それも内部よりの吸収変化によ って，10日目に比較して，著しくすう粗化が進行してい る.

さらに, 以上の変化と関連するように, 近接する霜慒 骨内部にも吸収によるすう粗化が始まっている.

ラベリング像でみると，いずれの側でも，移植床底部 や側壁部から増生した新生骨梁は骨移植後14日間，4 日 間隔で注射されたテトラサイクリンでラベルされてい る、その範囲は移植床内部だけでなく，それと隣接する 第 3 小臼歯や第 1 大目歯の間を占めている歯槽骨内部に まで及んでおり，この部の新生骨が活発に形成されてい ることがわかる。しかも，移植前28日間，4 日間隔で注 射したカルセインによるラベリング部は，移植床底部と 

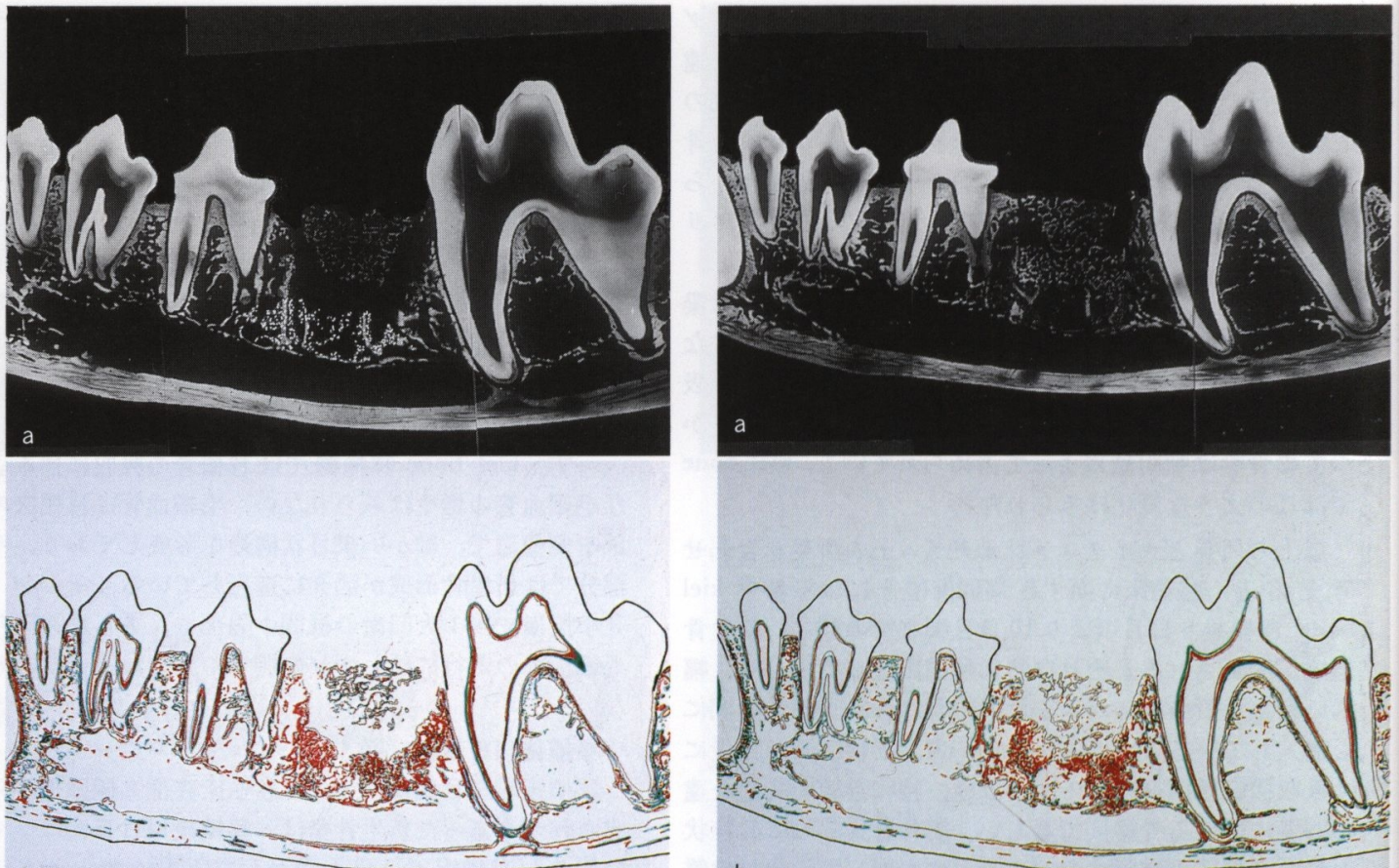

b
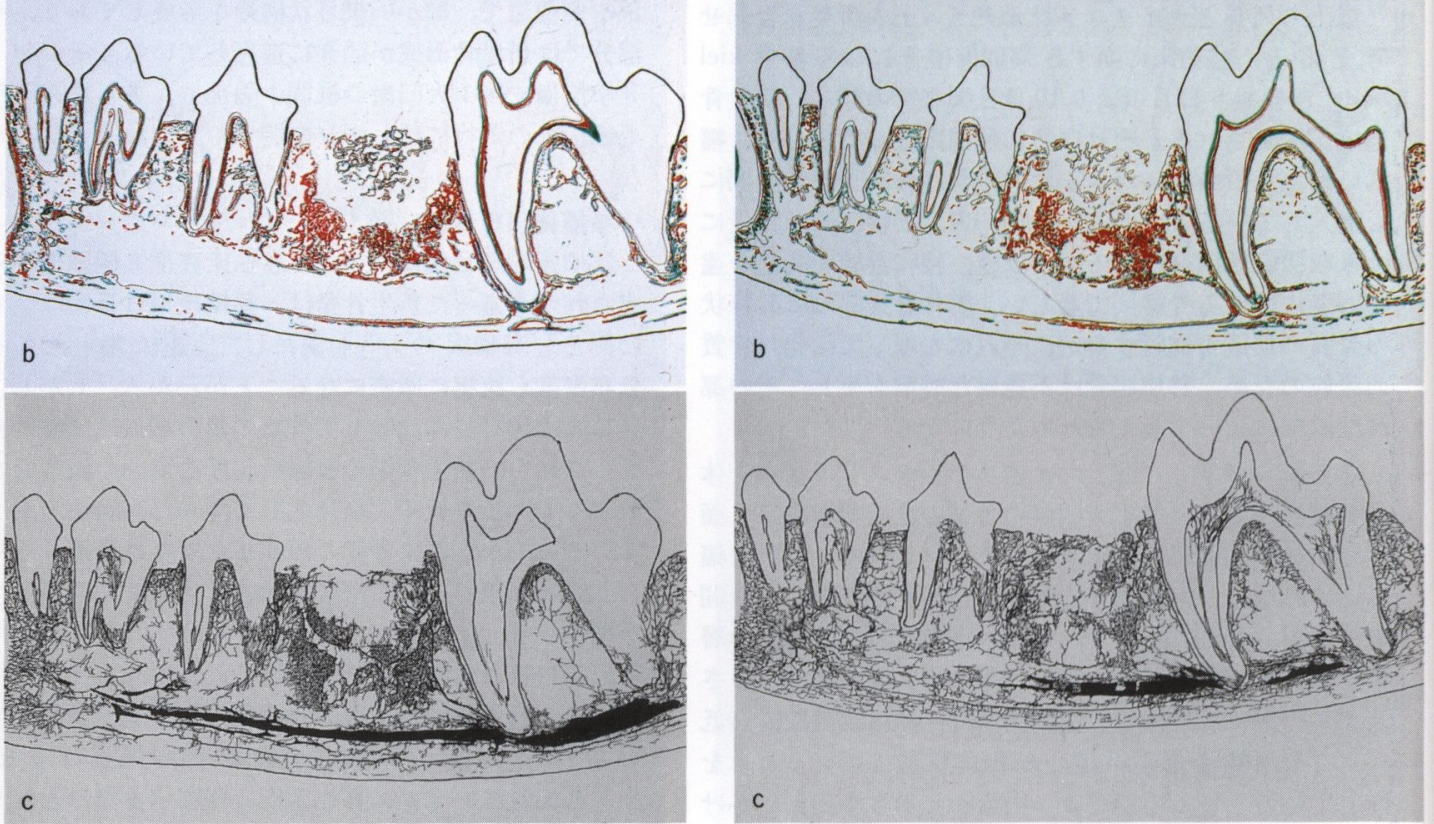

腸骨移植側
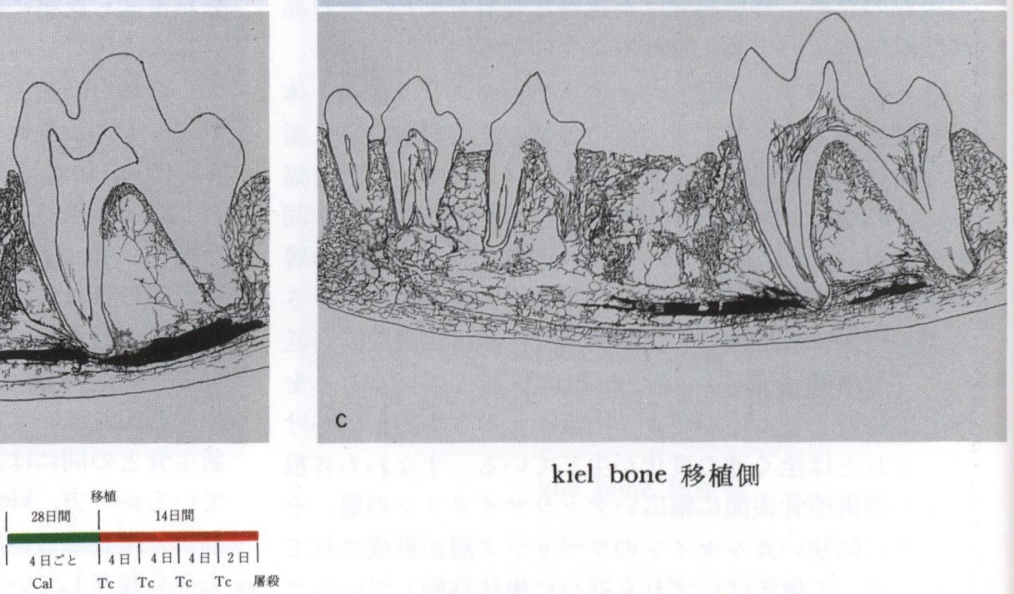

kiel bone 移植側

図 3 移植後 14 日目例

$\mathrm{a}$
$\mathrm{b}$
$\mathrm{b}$ マベリング像(トレーシング図 $)$
$\mathrm{c}$

側壁部の新生骨（仮骨）の骨梁間にはほとんどみい出さ れない，隣接する歯牙の間を占める歯槽骨内部にわずか に残存するだけである.

これらの所見とマイクロラジオグラムの所見をあわせ 考えると, 移植後14日目頃には, 移植床底部や側壁部で
は一方的に新生骨の形成が活発に進行し，この部は新生 骨梁によって次第に緻密に占められるようになる。とこ ろが，移植床と隣接する歯牙との間を占める歯槽骨内部 では，まず既存の骨の吸収が活発化する。勿論, この部 飞も新生骨の形成が開始されるが，吸収が形成量を上ま 

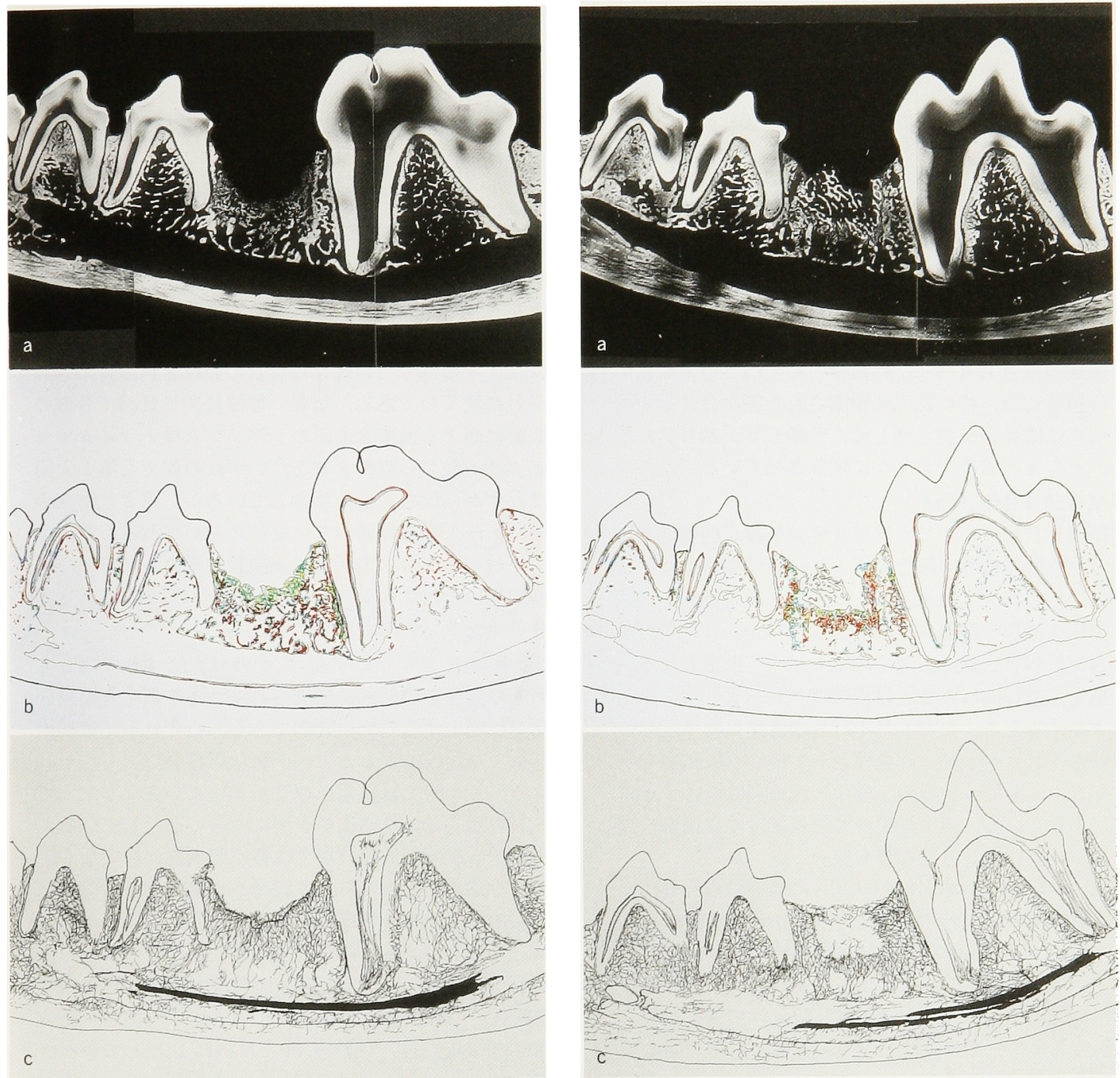

腸骨移植側

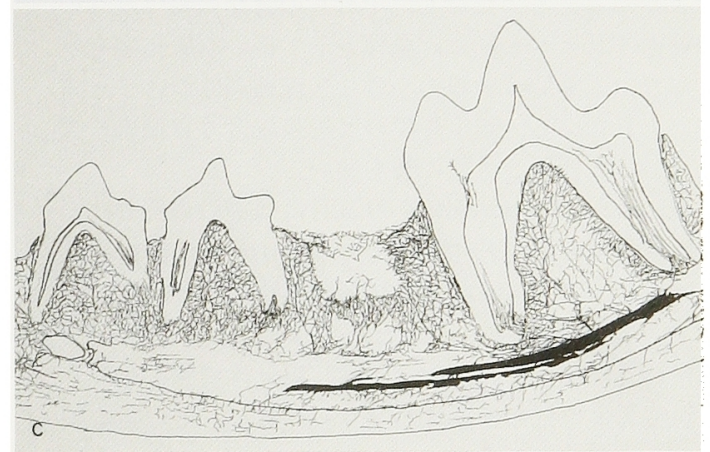

kiel bone 移植側

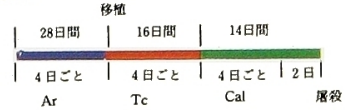

図 4 移植後30日目例

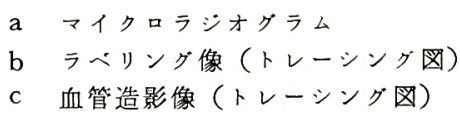

わって進行しており，そのためこの部は次第に多孔化す ると考党られる.

なお，この例でも移植後 10 日目例と同様に，歯牙移動 に伴ら歯槽骨の歯根膜表面でのラベリング像がみられ， 第 1 大臼歯は遠心に，第 3 小田歯は近心に歯体移動して
いることがわかるまな，移植床の下方の下顎管に面す る下縁部緻密骨の表層にはテトラサイクリンでラベルさ れた新生骨の形成が出現する。

アンギオグラムでは，腸骨移植後14日目頃に，移植床 の側壁と両隣接歯との間を占める歯槽骨内部に比較的太 
い血管の走行が出現する. そのうち移植床に隣接する遠 心曾槽骨内部に出現した血管は比較的長い経路によって 第 1 大四歯近心根尖付近の下歯槽血管より分枝している ことがわかる．近心側ではその経路はあきらかでない，

いずれにしてもそこから分枝した毛細血管は，移植後 10日目例の(1)，(2)の領域に細長い毛細血管網を形成し， ともに移植骨の骨梁内や, 移植床の底部や側壁部の新生 骨の骨梁表面に進入しているようにみえる，その分布密 度は移植後10日目例より著しく高い。

Kiel bone 移植側でも移植床と両隣接歯の間を占める 歯槽骨内部に細長い毛細血管の網目状構造が形成され， 吸収過程の進行している移植骨の骨梁内へ進入してい る、移植骨周囲，特に底部に形成された新生骨骨梁表面 の各所には腸骨移植側と同じく，毛細血管が網目状に増 殖し，その分布密度をわずかに増加させている。

\section{移植後30日目例（図 4)}

移植後10日目に，すでに移植骨底部や遠心側壁部から 開始された吸収機転の進行によって，移植腸骨は移植後 30日目以前に消失する。それとは逆に，同じ時期に凬囲 の移植床の底部や側壁部から形成されつつあった新生骨 梁は移植後14日目以降急速に増生し，太く緻密となる。

この結果, 全体的にみると移植床はクレーター状に陷凹 したようにみえる、ただし，それらの骨梁の幅は既存の 歯槽骨のそれよりも細く，全体として低い石灰化度を示 しており，骨梁間は多数の小さなX線透過性のスペース で占められている．新生骨梁のX線吸収度は移植床の表 層に近いほど低く，骨梁の幅も狭い。

一方, kiel bone は移植後 30 日目にはその大部分は吸 収され消失するが，わずかにその一部が移植床内に残存 している。新生骨梁は kiel bone の周囲の移植床の底 部や側壁部から形成されるために kiel bone 移植側で は箱型の移植床がまだ認められる.腸骨移植側に比較し て, 新生骨梁の分布密度はわずかに低く, その幅も狭 い.

ラベリング像を観察すると，いずれの側とも移植床周 囲の骨梁には移植前28日間注射したアリザリンコンプレ クソンによるラベリング部はみられない。それは腸骨移 植側では第 2 小臼歯の近心根, kiel bone 移植側では第 2 , 第 3 小臼歯の近心根の根間中隔部の歯根膜に面する 䨑槽骨表面の一部にテトラサイクリンのラベリング部に 接してわずかに認められるだけである，すなわち，移植 前に形成された骨梁のほとんどは, 移植後に生じた活発 な改造現象によってテトラサイクリンやカルセインでお きかえられたものと想像される，移植床を埋める新生骨 梁は，表層部分を除いてほとんどが，移植直後から16日 間 4 日間隔に注射されたテトラサイクリンでラベルされ ている，それに続いて，移植後16日目より14日間のカル セインによるラベリング部は, 移植床のテトラサイクリ ンのラベリング部の表層に幅狭い帯状に形成され，その
ほか移植床の深層で, テトラサイクリンでラベルされた 新生骨梁の表面に沈着して散在性に認められる.

以上の所見とマイクロラジオグラムの所見とから, 移 植床周囲の新生骨の形成は, 移植後16日間で活発に進行 し，このため骨梁は急速に太く，緻密になる．新生骨の 形成はそれ以降も引き続き進行し，30日目までに移植床 の表層に向って活発な骨質の形成がみられ，また移植床 の深層では既存の新生骨梁に添加するために, 新生骨梁 はますます太く，緻密になることがわかる，ただし，新 生骨形成は移植床周囲だけではなく，さらに遠隔部の第 2 小罒歯から第 1 大臼歯の根間中隔部の広い範用に拈よ び，まずその部分での既存の骨質の吸収と新生骨の添加 がそれに続くのである。なお，移植後30日目例で各根の 歯根膜に面する歯槽骨表面のラベリング像とマイクロ ジオグラム像から判断すると，いずれの側でも第 1 大臼 霜はわずかに遠心に歯体移動しているが，第 2 ，第 3 小 目歯は，ほとんど移動していないことが推測される。 た，下縁部緻密骨の表層で，下顎管に面する部分には腸 骨移植側にのみテトラサイクリンとカルセインによる新 生骨のラペリング部が出現する.

アンギオグラムでまず気づくのは，いずれの側とも 移植床の底部や側壁部に形成されつつある新生骨梁周囲 に活発に増生する毛細血管網である。いずれも，移植床 の深層では比較的太い血管網が粗な網目を形成し，それ が次第にきわめて細い毛細血管が互いにかさなりあって ループを形成し，移植床の表層に向って進行しているよ らにみえる。毛細血管の増生は移植床周囲だけでなく， さらにそこより離れた第 2 小目歯から第 1 大臼歯にわた る根間中隔部の歯慒骨内でもあきらかで，下顎管から枝 分れした小血管は各根の根間中隔部の歯槽骨内でさらに 小血管に分枝し，互いに網目状を形成して移植骨周囲や 歯根膜付近の歯槽骨内に進入しているようである。その 分布密度は全体的に移植後 14 日目例に比較してかなり 緻密である。な拉，まだ吸収されずに残っている kiel bone にも周囲から毛細血管が増生し進入する，その配 列は移植後14日目例に比較してやや緻密である。

\section{移植後46日目例（図 5)}

ここでは，移植床の底部や側壁部からばかりでなく， 移植床頂部付近から移植床の内方へ向かって新生骨の形 成が活発化する，すなわち，いずれの側でも移植床の内 方に向からに従って，きわめてX線吸収度の低い，針状 もしくは樹枝状の 新生骨梁が 緻密に配列するようにな る. その分布密度は移植後30日目に比較して著しく緻密 であるが，腸骨移植側では骨梁の幅の増加は比較的少な い. そこでは, かつて存在した移植腸骨の部分に新生骨 梁が緻密に配列するのであるが，その方向はきわめて不 規則である。

一方, kiel bone 移植側ではこの時期でも依然として 移植骨はほとんどが吸収されているが，なお不規則な外 
Vol. 34 No. 9 骨移植に続く歯槽骨変化のマイクロラジォグラフィ, ラベリング法と血管造影
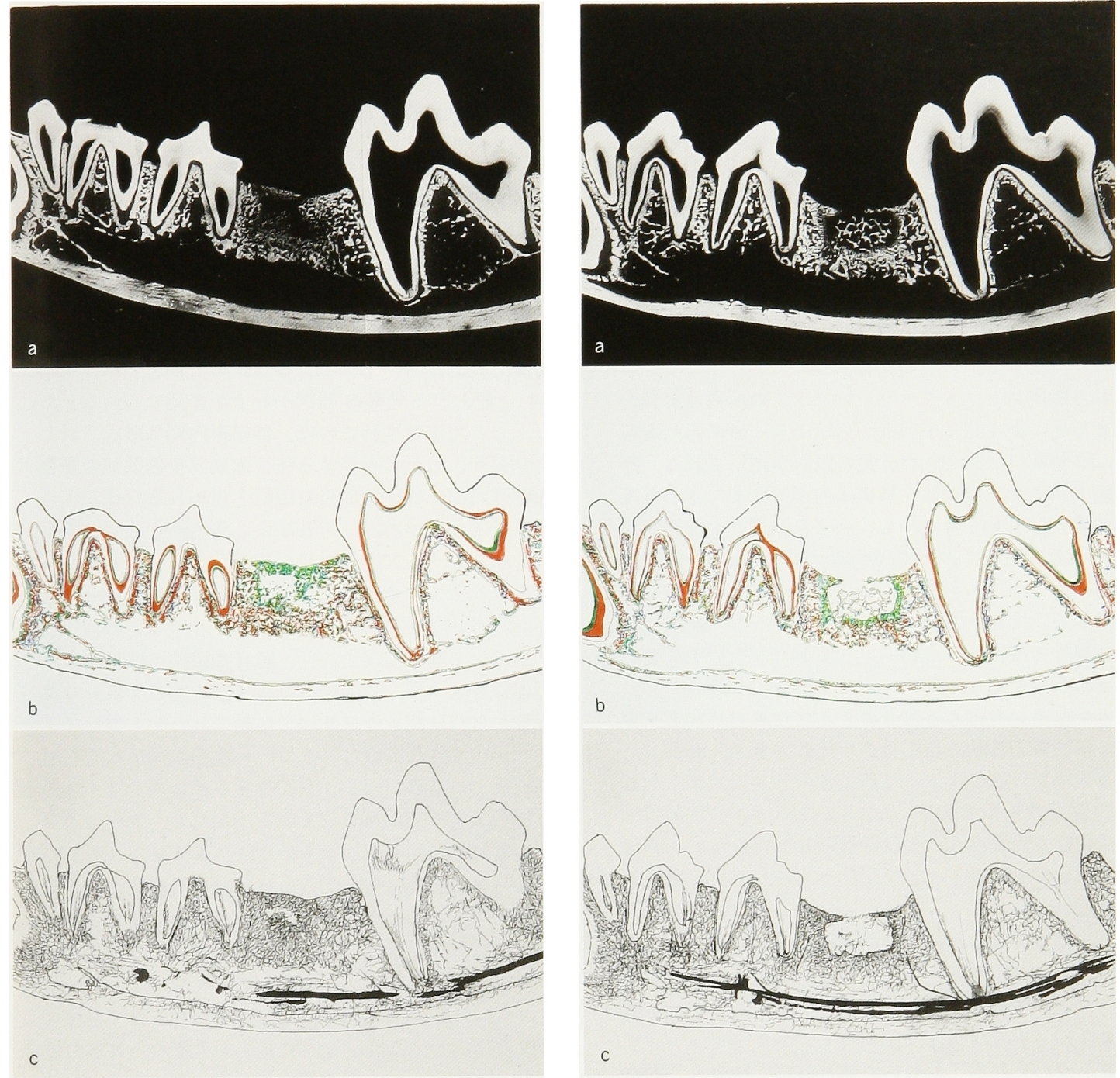

腸骨移植側

b

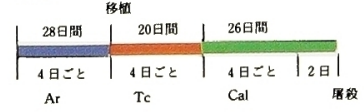

kiel bone 移植側

图 5 移植後46日目例

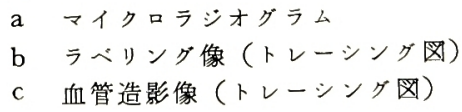

形を保っている．移植床内部の新生骨梁は kiel bone を 囲むように周辺からある程度規則的に配列して，細い新 生骨梁を内方に向け増生しているょうにみ学る。その周 辺部の新鮮骨梁のX線吸収度は腸骨移植側と同様に，既 存の歯槽骨のそれよりかなり低いが，移植後 30 日目以
後，急速に骨梁の幅を增しているようにみえる。

ラベリング像では，いずれの側も移植床外側の骨梁の ほとんどは，移植直後から20日間，4 日間隔で注射した テトラサイクリンによってラベルされる. 一方, 移植床 のさらに内方と頂部を含む骨梁は移植後20日目より26日 
間のカルセインによってラベルされていることがわか る.ここにはかつて, 移植前28日間アリザリンコンプレ クソンでラベルした骨梁が存在したが吸収され，わずか に移植床の底部に散在性に認められるにすきない，テト ラサイクリンのラベリング部はこれより離れた各根の周 囲の固有歯槽骨や支持骨の骨梁にも多量に分布し，その 表面の各所にカルセインでラベルされた骨梁が添加して 不規則に配列している.テトラサイクリンの分布密度に 比較してカルセインのそれはわずかに低い。なお，アリ ザリンコンプレクソンは各根の歯根膜に面するテトラサ イクリンのラベリング部の内側にわずかに存在するのみ である。

これらの所見とマイクロラジオグラムの所見とを合わ せ考えると，まず第 2 小臼歯から第 1 大臼歯にわたる各 所で，移植前に形成された骨梁の吸収が開始される。 れに続く新生骨の形成は，移植床内部ではまだきわめて 活発に進行しており，しかも，いずれの側とも移植骨の 吸収の進行に伴って, 周囲から新生骨の形成が活発化 し, 移植床の内方に向かって練い骨梁を形成しているこ とがわかる。すなわち，ここでは移植床内部の新生骨形 成は移梢骨と监換する過程によって進行していることが 想像されるのである。それに対してそこより離れた部分 ではカルセインの占める割合はテトラサイクリンより少 なく，移㮌後20日間，新生骨の形成は活発化したが，そ の後改造機転の低下によって新生骨の形成も低下したこ とが想像されるのである。たたし，kiel bone 移㮌側で は移植骨はまた残存し，吸収が進行しているために腸骨 移植側に比較してカルセインでラベルされた新生骨の形 成は少ない。

なお，移植後46日目例ではいずれの例とも，各根の米 根膜に面する歯槽骨表面には，X線吸収度の比較的高 い, テトラサイクリンでラペルされた不規則な幅の骨梁 が形成され，その内側にはカルセインによる細いラベリ ンク部が認められる。これらの所見から，移植後，隣接 する歯牙にはあきらかな方向への歯体移動は現れなかっ たものと思われる，また下顎管に面する下縁部徵密骨の 表面とは，いずれの側ともテトラサイクリンによるラへ リング部が認められる。 アンギオグラムでは移植床の周 明で，両隣接歯に面する慒間中隔部や，移植床の底部や 側壁部から内方に向からに従って，ますます緻密な毛細 血管網が観察される. 特に腸骨移植側では細い新生骨梁 にひとつひとつを取り囲むように，毛細血管がループ状 に增生し，緻密な絧目状構造を形成している。その分布 密度は移植後30日目例に比較してもかなり高い。

一方, kiel bone 移植側の分布密度はそれほどの変化 はない，たたし，kiel bone の周囲に形成された新生骨 梁の配列方向とほぼ一致して細い毛細血管が内方に向か って瀻毛状もしくは放射状にかなり做密に配列し, 増生 しているょらにみえる。

\section{移植後62日目例（図 6)}

マイクロラジオグラムでは，いすれの側とも新生骨梁 は移植床を満たすように急速に増生し，その幅も太くな る。特に，腸骨移植側では，新生骨梁の走行は移植床頂 部へ向かって緻密に配列し, 骨梁の幅も移植後46日目に 比較してかなり太く, そのX線吸収度も次第に周囲の歯 槽骨のそれに近くなることがわかる，もはや，移植腸骨 は吸収され全く認められない,一方, kiel bone 移植側 では腸骨移植側に比較して低いX線吸収度の新生骨梁の 細い絧目状のつらなりが認められる。それは移植床の媔 部付近を含む周囲から内部に向かって不規則に增生して いることがわかる。 しかし，移植床の底部付近には kiel bone と思われる骨梁の残政がわずかに認められる．た だし，ここで注目されるのは，移植床内部に形成された 新生骨梁や，それに隣接する移植床底部や側壁部の既存 の歯慒骨内部にはすでに吸収機転と思われる変化が開始 されていることである。それは，各所で大小不同の不規 則な外形を有するX線透過像を形成しており，さらに移 植床頂部の新生:骨梁の表面にすわずかな吸収像がみられ る.この変化は特に腸骨移植側であきらかに認められる。

ラベリング像で観察すると，腸骨移植側では移植床の 表層部分を除いて，内部を占める新生骨梁の大部分は移 植直後か528日間，4 日間简で注射されたテトラサイク リンでラベルされている。そこから表層に向かって移植 後28日目より34日間同じように投与されたカルセインに よるラベリング部が連続している。たたし，カルセイン による表層部のラベリングの中にはテトラサイクリンの ラペリング部が散在性に認められ，逆に底部ではテトラ サイクリンのラベリングに混じってカルセインによるラ ベリング部が存在していることにも注意しなければなら ない。ここでは移植前，投与したアリザリンコンプレク ソンのラペリング部はみられない。それは各根の菌根周 囲の歯根膜に面する歯慒骨内にわずかに認められるたけ である

一方, kiel bone 移植側では腸骨移植側に比較してカ ルセインによって占められるラベリング部が広いことに 気つくのである。テトラサイクリンのラベリング部は主 に，移植床底部の既存の雨槽骨にみられ，汪かはカルセ インのラベリング部の中にわずかに散在しているたけけで ある。

これらの所見とマイクロラジオグラムの所見を合わせ 考えると，移植床内部で開始された新生骨梁の形成は移 植後28日目をすきてもなお活発に進行し，このため新生 骨は頂部に向からに従ってX線吸収度の低い細い網目状 の骨梁の配列によって占められるよらになる、ただ， 腸骨移植床内の新生骨の形成様式は移植後46日目例のそ れとはあきらかに異なり，かえって30日目例のそれに類 似しているようにみえる。なぜなら，ここには周用から 移植休の内方へ向かって移植骨と監換するような新生骨 

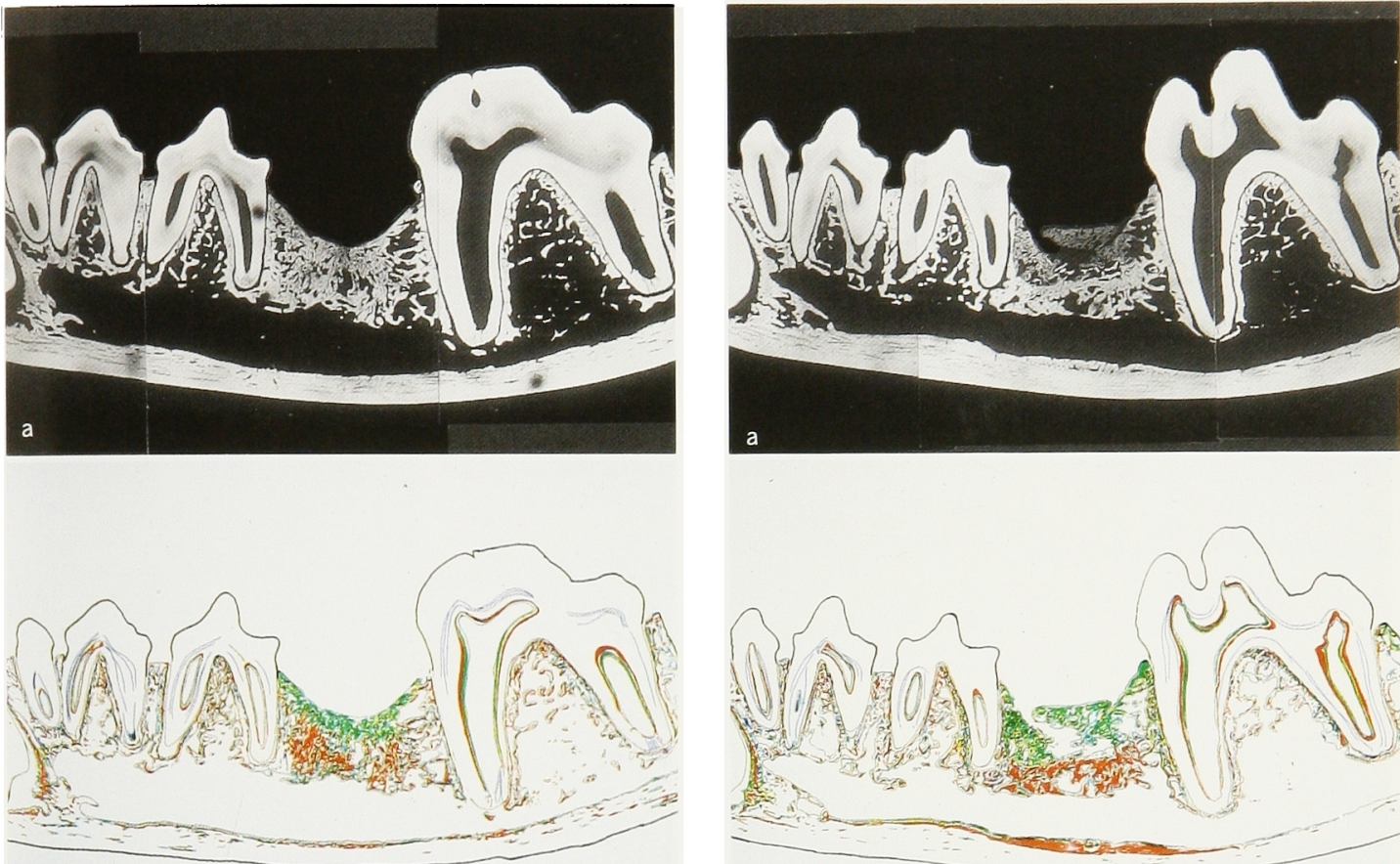

b

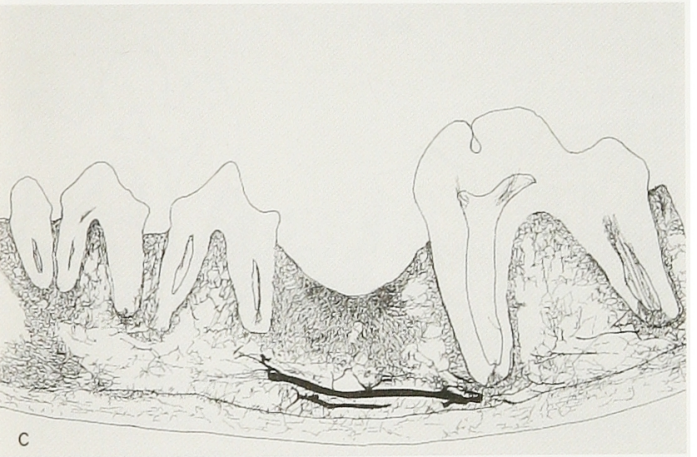

腸骨移植側

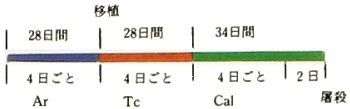

kiel bone 移植側

図 6 移植後 62 日目例

a マイクロラジオグラム

b ラペリング像（トレーシング因）

c 血管造影像(トレーシング四)

梁の形成がみられないからである、すなわら, すず, 移植 骨の底部や側壁部で吸収が開始され，頂部へ向かって進 行する。それに続いて，吸収によって生じたスペースに 移植床の底部や側壁部から新生骨梁が增生し, 移植床の 頂部へ向かって緻密に配列するようになるのである。こ の5ち, 移植後最初の 28 日間に活発に形成された新生骨
梁は腸骨移植床の底部や側壁部に多量に存在しているの に, kiel bone 移植側ではその新生骨のほとんどは移植 後28日目以後に形成されたものであることがわかる。さ らに腸骨移植側では，移植床周囲の既存の歯槽骨にもあ きらかな吸収機転が進行する。このことから kiel bone 移植側では腸骨移植側に比較して移植骨の吸収の遅れに 

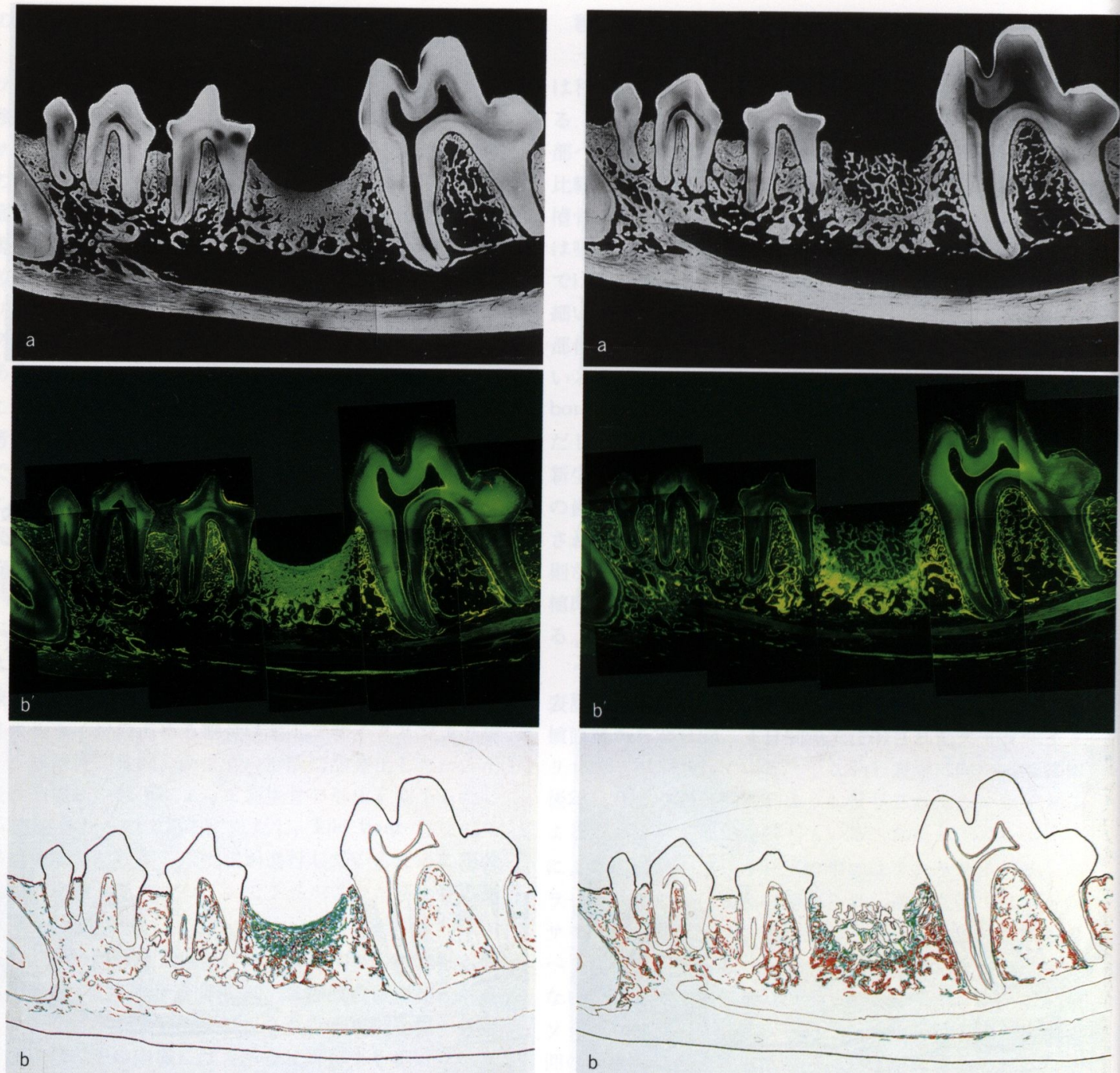

腸骨移植側
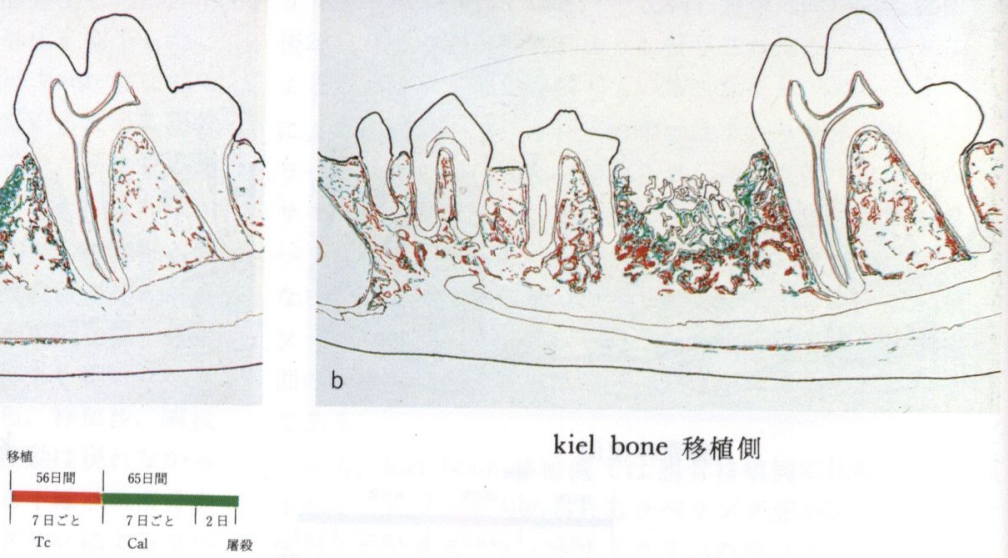

kiel bone 移植側

図 7 移植後 121 日目例

$$
\begin{aligned}
& \mathrm{a} \text { マイクロラジオグラム } \\
& \mathrm{b}^{\prime} \text { ラベリング像 } \\
& \mathrm{b} \text { ラヘ・リング像 (トレーシング図) }
\end{aligned}
$$

よって，それに続く新生骨形成やその改造性変化にも遅 れが生じたことが想像される。なお，移植後 62 日目例で も，いずれの側とも各根の雪根膜に面する歯槽骨表面 は, テトラサイクリンによってラベルされ，そのX線吸 収度は既存の固有歯槽骨のそれ飞近く, 移植後, 隣接す る歯牙にはあきらかな歯体移動は起こらなかったものと
思われる。

さらに, kiel bone 移植側では移植床底部の歯槽骨に は, 移植後28日間のテトラサイクリンでラベルされた新 生骨の形成が活発化するがその下方の下䫇管に面する下 縁部緻密骨の表層には幅広いテトラサイクリンのラベリ ング部に接して幅狭いカルセインのラベリングが観察さ 


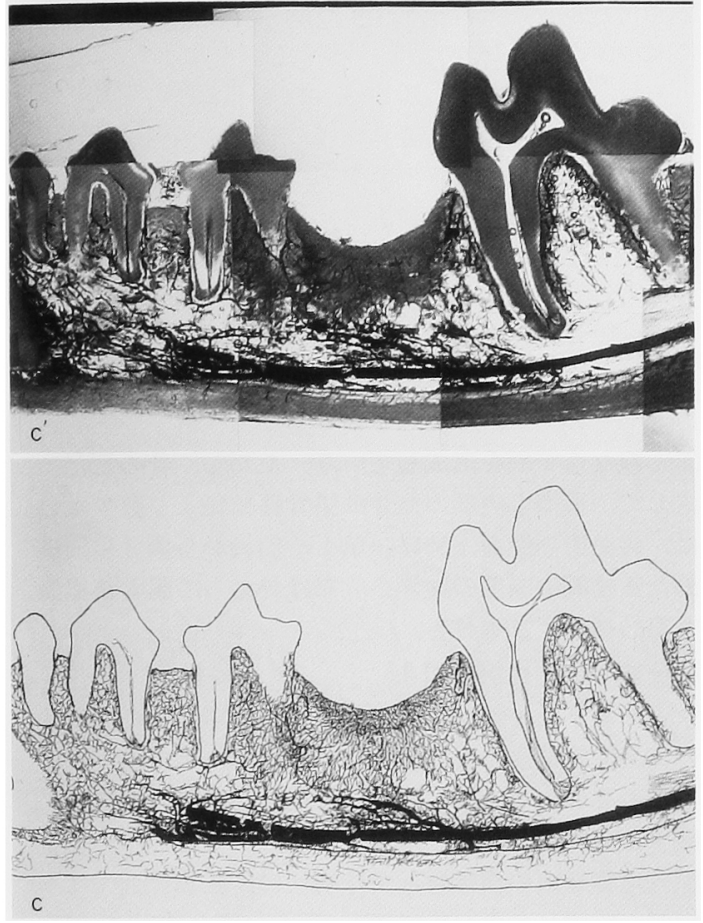

腸骨移植側

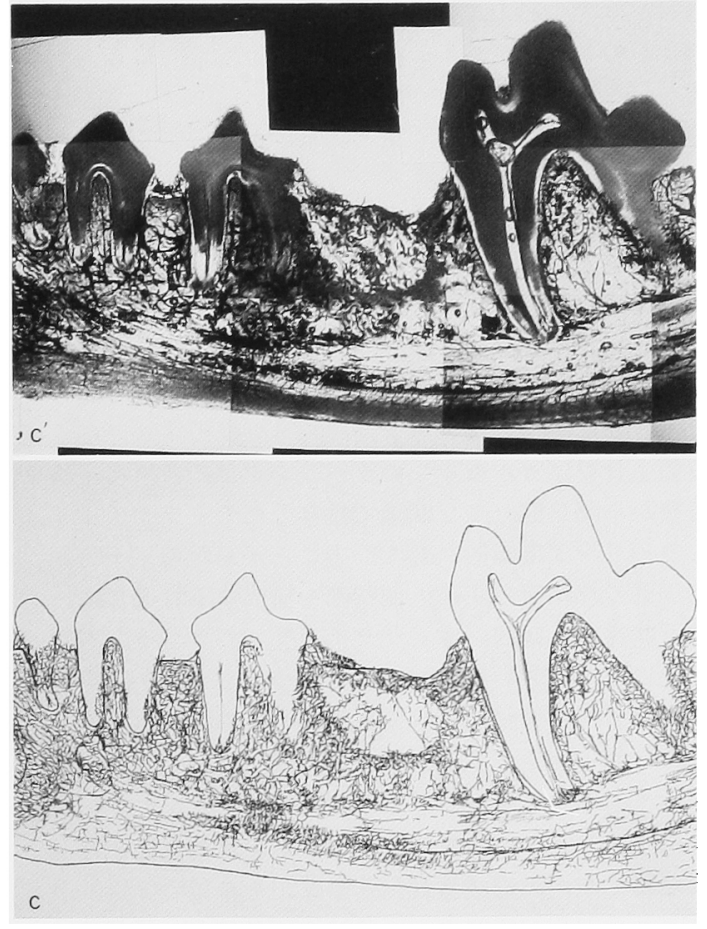

kiel bone 移植側

\title{
図 7
}

\author{
! 血管造影像 \\ c 血管造影像（トレーシング図）
}

れる、下買管に接する維密骨の泌化は，腸骨移植例でも 観察されるが，ラベリングの像は kiel bone 移梢例で あきらか洉い。この变化は, 移植後28日間活発に進行 するが，それに続く34日間は低下することがわかる。 こ れらの事実は扰そらく, kiel bone の吸収のおくれによ って生じた下嵿骨の支持力の欠陥を補填するために形成 された一種の『裹打ち現象』ともいうべき变化と考えら れる。

アンギオグラムでは，腸骨移植側の下慒血管より分 枝した比較的太い血管が新生骨梁の周囲に進入し，枝分 かれしておのおのの骨梁を囲むようにさらに細い毛細血 管網を形成し，移椎後30日目例と同様に移植床の頂部に 向かって維密に配列するようになる。そ分布密度は移 植後46日目のそれよりわずかに高い

一方, kiel bone 移植側では，その分布密度は腸骨移 植側と類似しており緻密な毛細血管の配列が認められ る、たたししここではその配列は腸骨移植側に比較してや や不規則で球心状の配列はみられず，また下槽血管よ りの枝分かれは不明膫である。ただ第 3 小臼茵から第 1 大曰雪に及ぶ雪㡟骨内部には腸骨移植側に比較してょり 維密に配列寸る血管䋨が観察される。

\section{移植後 121 日目（图 7)}

マイクロラジオグラムでは，腸骨移植床を満たす新生 骨梁は，移植後 62 日目よりますます緻密に配列し，骨梁 の幅む太く，周围歯㡟骨に匹敵するほどのX線吸収度を 示すようになる，その骨梁の配列は，頂部へ向からよう に增生し，頂部付近では，方向をかえて層状に配列して いるよらにみえる。このため移植床は移植後46日目例と 異なり，30日目，60日目例と同しょうに全体的に陥凹し， 上方にクレーター状を呈している。 ところが kiel bone 移植例では，移植床の大部分は kiel bone の残䈞と思 われる不規則に吸収された骨梁の配列によって占められ ているのが観察される，その骨梁の幅はさまざまで，石 灰化度は周囲歯㡟骨のそれに近く，不規則な網目状を形 成している，ただし，移植床の底部や側壁部には移植後 わずかに形成された新生骨梁のつらなりが諗められる。 そこでは既存の歯慒骨との境界はもはやあきらかではな いが，確かに周国歯情骨に匹敵する骨梁の幅とX線吸収 度を有する新生骨梁が故密に配列しているのが認められ る、ただし，ここで注目されるのは，特に腸骨移植側の 新生骨の骨梁内部だけでなく，移植床の底部や側壁部を 構成する骨梁の各所は吸収の進行によって不規則なX線 
透過像を形成していることで，これらの部分で新生骨の 形成とその 2 次的改造が，平行して進行していることが 想像されるのである。その他，それより遠隔部の歯槽骨 の骨梁には大きな変化は認められない.

ラベリング像で観察すると, まず, 腸骨移植床の内部 を占める新生骨梁の大部分は, 移植後56日目より65日間 ラベリングしたカルセインによってラベルされているこ とがわかる，これを細かく観察すると，移植床頂部を占 めている，マイクロラジオグラムで層状に配列する骨梁 に相当する部分では，ほとんどがカルセインでラベルさ れているのに，その下方の球心状あるいは網目状に増生 する新生骨梁はカルセインのラベリング部の各所に, 移 植直後から56日間，7日間隔で投与したテトラサイクリ ンのラベリング部が散在していることがわかる. 一方, その周囲の移植床の底部と側壁部を構成する骨梁では, これとは逆に，幅広いテトラサイクリンのラベリング部 の周囲には, 幅狭いカルセインのラベリング部が認めら れ，その各所の骨梁は吸収で生じた不規則な軟組織でお きかえられている。

このことは, 移植床とその周囲の骨梁に，次に述べる 変化が生じたことを示唆している．すなわち，移植後56 日間に移植床内に形成された骨梁は，その後の 2 次的改 造により大部分が吸収され，移植後56日目より65日間に 形成された新生骨梁によって扰きかえられる。この新生 骨梁はその後さらに移植床の頂部に向かって層状に増生. する.また，移植床の周囲の骨梁には移植後56日間，新 生骨形成が活発化するが，この変化はその後，急速に低 下し，かえって吸収の進行によって各所に多孔性の骨の 欠損像を形成するようになるのである.

一方, kiel bone 移植床内部の不規則に吸収された骨 梁はカルセインによって均一にラベルされている。ただ し，そのごく一部にはテトラサイクリンのラベリング部 が観察される，さらに移植床の底部や側壁部の内壁は, カルセインでラベルされた不規則に出入する骨梁で占め られており，その周囲のテトラサイクリンで幅広くラベ ルされた骨梁によって裏打ちされた形態を呈している。 もはや既存の歯槽骨との境界はあきらかでない.

このことは, 移植床内の kiel bone が, 移植後, 一 方的に吸収されるのではなく，たえずその周囲に新生骨 の添加を伴い，こうした添加と吸収を繰り返しながら次 第に吸収され，新生骨に置換されてゆくといら複雑な過 程を進むことを想像させるのである。

さらにここでは次の変化にも注意を払わねばならな い.すなわち, kiel bone 移植床の底部や側壁部だけで なく，そこより離れた歯槽骨，特に第 3 小臼歯の根間中 隔部や第 1 小臼歯から第 3 小眠歯にわたる根尖部付近の 畨槽骨の骨梁では, 腸骨移植側に比較してテトラサイク リンにラベルされた骨梁があきらかに多いのである，腸 骨移植側では骨移植後, 周囲歯槽骨内部にも新生骨形成
が活発化するが，それは次第に吸収の進行によって多孔 性になるが, kiel bone 移植側のこのような変化はこう いった吸収の羊れによって出現したものと考えられる。

アンギオグラムでは腸骨移植床の底部や側壁部から比 較的太い血管が新生骨梁内に進入する。その血管は骨梁 の走行に沿って, ますます太く, 樹枝状もしくは球心状 に配列するようになり網目状の血管網の先端はさらに枝 分れして細かいループを形成する。，一方，kiel bone 移 植側では腸骨移植側に比較して細い血管が移植床の骨梁 間に進入して不規則に分布していることがわかる。いず れの側もその分布密度は62日目に比較して低下して，い くぶん粗な血管網を形成している，ただし，骨の変化に 対応して, 移植床内部の血管は腸骨移植側より数少ない のに, 移植床周囲の, 特に, 第 1 小臼画から第 3 小臼歯 にわたる槽間中隔部の血管の分布はかえって腸骨移植側 より高いのが注目される。

\section{移植後 142 日目例（图 8)}

マイクロラジオグラムでは，この時期になると，いず れの例とも移植床の内部を満たす骨梁は，ほほ隣接する 歯槽頂の高さにまで増生し，ほぼ周囲の既存の歯槽骨に 匹敵する太さとX線吸収度を示すよらになる。その督梁 の配列は移植床の頂部付近では層状に，底部付近では不 規則で，いずれもさわめて高い石灰化度を有する 部分 と，きわめて低い石死化度を有する部分とが互いに入り 混じってモザイク模様を呈しているのが観察される。 はや移植された kiel bone は吸収され消失している。い ずれの側でもかつての移植床の境界はあきらかでない. この部のラベリング像を比較すると，高石灰化の部分は 移植直後から84日目までテトラサイクリンによって，低 石灰化の部分は85日目より142 日目までのカルセインに よってラベルされており，これらの骨梁の配列の間の， 特に低石灰化部分に接して大小不同の軟組織が介在して いる，それは腸骨移植床底部では吸収の進行によって著 しく多孔性であるが, kiel bone 移植側ではテトラサイ クリンによってラベルされた高石死化度の骨梁で占めら れている。これらの所見からも移植床の内部やその周囲 の骨では，移植後142 日目の段階でも，なお引き続いて 改造機転が進行していることがわかるのである.

その他，いずれの側とも下顎管に面する下縁部緻密骨 の表層にわずかにカルセインのラベリングがみられるほ か, さらに遠隔部の骨梁には著しい変化は認められな い.また，移植床に隣接する歯牙にはこの間，どの方向 にもあきらかな歯牙移動は起こらなかったものと思われ る.

アンギオグラムで観察すると，いずれの側でも下歯慒 血管より枝分かれした比較的太心小血管はさらに細く網 目状に配列しながら，移植床の底部や側壁部から骨梁の 走行にそって，新生骨梁間に進入してゆくことがわか る.このため移植床の頂部付近では血管の走行はかなり 

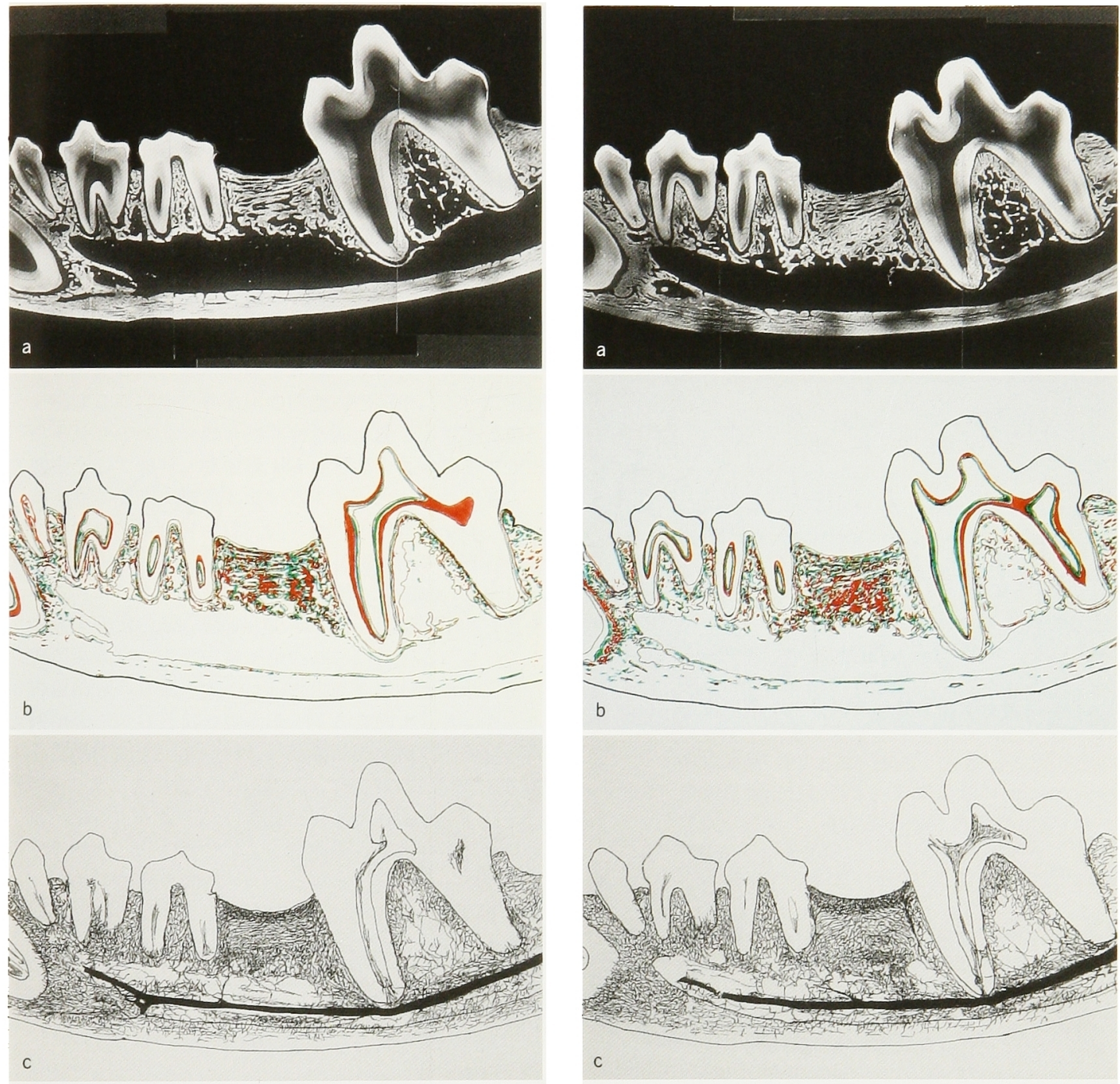

腸骨移植側

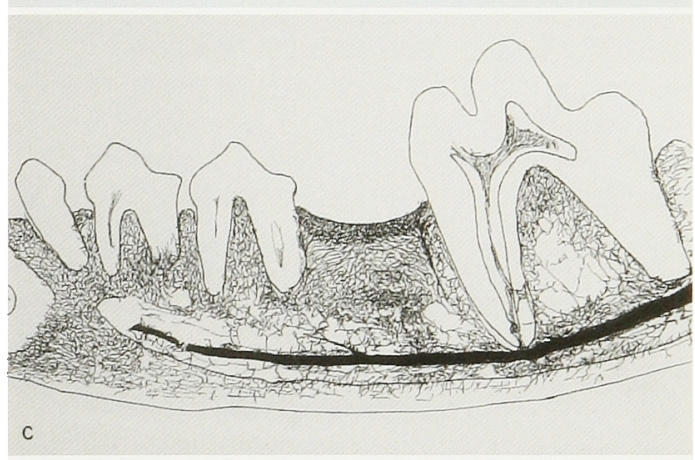

kiel bone 移植側

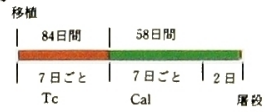

図 8 移植後142日目例

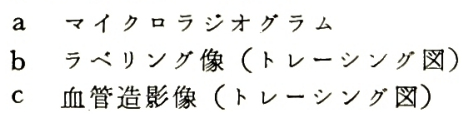

規則的な層状もしくは網目状を呈している.

一方, 䔟植床の底部では骨梁の走行に一致して血管の 走行もきわめて不規則であり，細い血管が互いにからみ 合いながら骨梁間に進入しており，不規則な網目状構造 を形成している。

\section{移植後 184 日目例 (図 9)}

マイクロラジオグラムでは腸骨移植床の内部や周囲に 形成される新生骨梁の配列や石灰化度は, 移植後 142 日 目例のそれにさわめて類似している。すなわち, そこで はX線吸収度の高い部分と低い部分とが複雑に入り組ん でモザイク模様を示す增状の骨梁のつらなりが認められ 

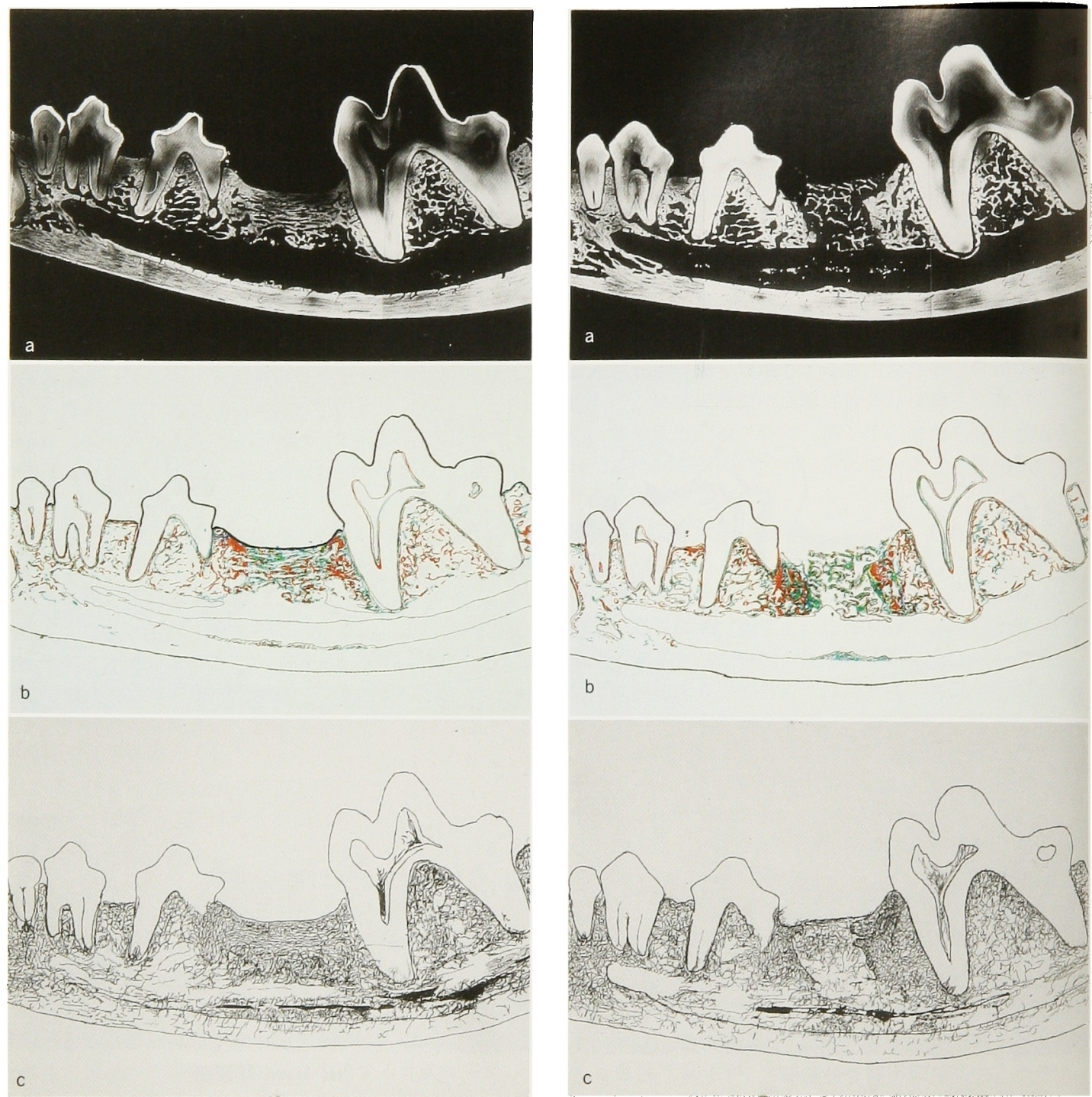

腸骨移植側

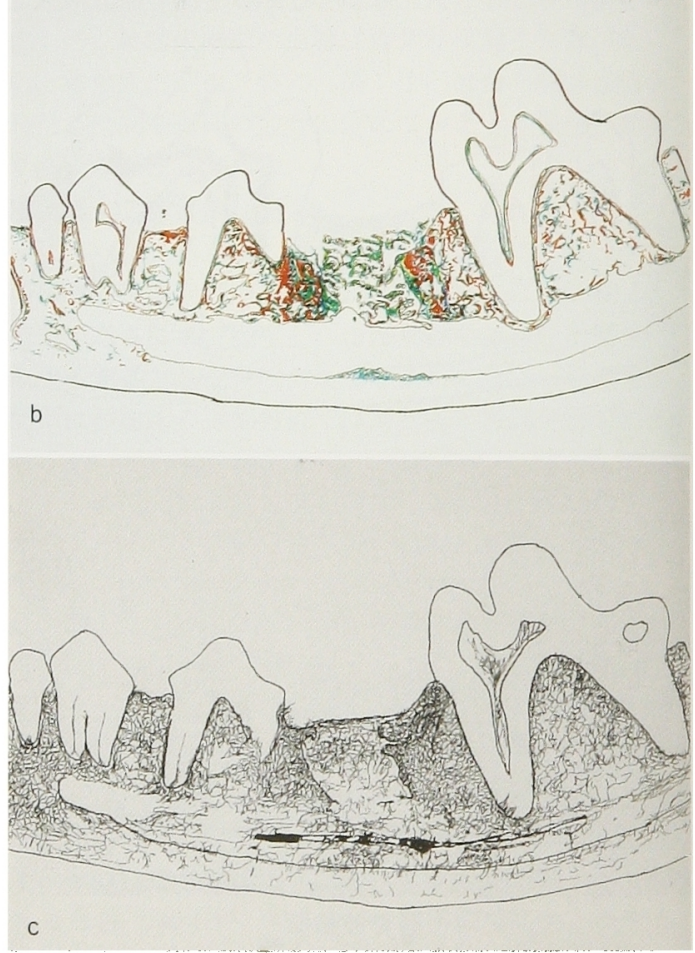

kiel bone 移植側

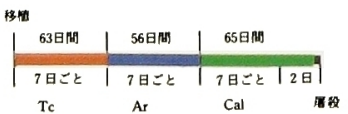

図 9 移植後184日目例

$$
\begin{aligned}
& \text { a マイクロラジオグラム } \\
& \text { b ラペリング像（トレーシング図） } \\
& \text { c 血管造影像（トレーシンク図） }
\end{aligned}
$$

る、ラペリング像で比較すると，X線吸収度の高い骨梁 は移植直後から63日間注射したテトラサイクリンで，低 い部分は119 日目より65日間注射したカルセインでラべ ルされており, カルセインのラペリング部は主に移植床 の頂部付近に，テトラサイクリンのラペリング部は移植 床の側壁部や底部に多く、そこでは不規則な外形を示す
骨質の吸収像が多く認められる.

これらのことから，移植床とその周囲を占める骨梁で は移植後 184 日目でもなお骨質の吸収と添加がくりかえ し, 特に, 移植床の頂部ではもっばら新生骨の形成が, 一方，底部や側壁部ではかえって吸収が活発に進行して いることがわかるのである。 
一方, kiel bone 移植側では，当初予想もしなかった 変化に出会らのである。すなわち、マイクロラジオグラ ムでは移植後 142 日目にはほとんどが吸収され，消失し てしまった kiel bone と思われる骨質の配列が，なお， 認められる。それは周曲の既存の歯槽骨に近いX線吸収 度を有しているが，各所で吸収され，細く不規則な外形 を保っている.

ラベリング像では，この骨梁はカルセインで均一にラ ベルされその辺縁にわずかにテトラサイクリンのラベリ ング部が認められる。すなわち, kiel bone 移植後, 骨 梁は短期間で吸収されず，そこに新生骨の添加と吸収を くりかえしたことが想像される. カルセインのラベリン グ部はこのほか, 移植床の側壁の内面や，さらに内部の テトラサイクリンのラペリング部に混じって不規則な形 熊を有しており，移植後 184 日目でもこの部分で骨の改 造過程が活発に進行していることがわかるのである.

移植後 142 日目には，いったん吸収されてしまった kiel bone と思われる骨質がなぜ移植後 184 日目でも移 植床内に存在しているのであろらか。歯髄内に形成され る前象牙質の量を比較してみると，移植後 142 日目例の 方があさらかに形成量が多いことがわかる，さらに既存 の歯槽骨の骨梁も太く，石灰化度も高いことなどから， 移植後 142 日目例の動物は 184 日目例より若いことがあ さらかである。すなわち，高年齢の動物では移植された kiel bone の吸収とそれに続く新生骨の形成や 2 次的改 造が腸骨よりも著しく遅れたことが考えられる。

その他，いずれの側とも移植床の下方の下顎管に面す る下縁部緻密骨の表層にはカルセインとテトラサイクリ ンのラベリング部が入り混じって不規則な新生骨を形成 しているのが認められる。 また，移植床に隣接する歯牙 にはこの間，あきらかな歯牙移動は起こらなかったこと がわかる.

アンギオグラムでも, 腸骨移植床内部や周囲にみられ る血管の走行やその太さは移植後 142 日目のそれとほと
んど変化はない。たたし，その分布密度はやや低下して いるよらにみえる。

一方, kiel bone 移植側の 血管の走行変化は, 移植後 121 日目例のパターンにきわめて類似している。すなわ ち, 移植床内部の移植骨の骨梁周辺にはきわめて粗な網 目状の血管のつらなりが認められ, さらに移植床の側壁 部には，下歯槽血管から枝分かれした血管と連絡するよ らに血管網が形成されていることである，いずれの部位 でもその分布密度は142 日目例よりもあきらかに低く， 121 日目例のものよりわずかに高いようである。

総括と考察，結論については，(2) に記載する.

\section{引用 文 献}

1) Ollier, J.L.: Traite experimental et clinical de la regeneration des oset de la production artificielle du tissu osseux. Masson et Fils Peris 1867 cit by 171867 .

2) Maatz, R. and Bauermeister, A.: A Method of Bone Maceration. AJ Bone Joint Surg 39: 153-166 1957.

3）千葉博茂：粕牙抜去に繶く歯槽骨变化のラベリ ング法とマイクロラジオグラフィによる研究. 歯基礎誌 18：1-52 1976.

4) 千葉博茂, 日比野好行，他：骨移植に続く迷槽 骨変化の研究 (第 1 報) 大研磨片の microradiogram による観察。（第 2 報）大研磨片の labelling 像による観察（会）。日口外誌 25：1632 1979.

5) 狩山昌方：三色螢光標示法によるワニの㐘と硕 骨の発育に関する研究。阪大荘誌 14:17-38 1969.

6) 堀田恵美子：生理的歯牙移動に伴5菌槽骨变化 のラベリング法とマイクロラジオグラフィによ る研究。菌基礎誌 21：1-29 1979. 